\title{
Destinations of Male Outmigration and their Drivers in Indian Sundarbans
}

\author{
Shatabdi Saha* and Rupak Goswami ${ }^{+*}$
}

\section{Abstract}

Economic liberalisation has created opportunities for semi-skilled labours within and outside India. This study investigates the male out-migration from the Sundarbans region of India with special reference to the choice of their destinations. Following a mixed-method approach, we collected data through a questionnaire survey, in-depth interviews, focus group discussions, key-informant interviews, and Participatory Rural Appraisal. Analyses revealed that migrants tended to travel to diverse inland and even to overseas destinations on a fixed condition, facilitated by pre-existing support networks. The decision on choosing a destination is regulated by several micro-level determinants such as migration chronology, education, and acquired skill, life cycle stage of the migrants, the expected amount of remittance, the reason for migration, and nature of the job at the destination. The destinations abroad are often preceded by migration to inland destinations leading to higher acquired skill and savings. Joint families, having the ability to support international travel and access to support networks, were more prone to reach international destinations.

Keywords: Male Out-migration; Choice of Destination; Correspondence Analysis; Sundarbans

\footnotetext{
¥ Research Scholar, IRDM Faculty Centre, Ramakrishna Mission Vivekananda Educational and Research Institute, Email: dearshatabdi@gmail.com

${ }^{\dagger}$ Assistant Professor, IRDM Faculty Centre, Ramakrishna Mission Vivekananda Educational and Research Institute, Kolkata-700103, West Bengal

*Email: goswamirupak@rediffmail.com

(c) 2020 Saha \& Goswami. This is an Open Access article distributed under the terms of the Creative Commons Attribution License (http://creativecommons.org/licenses/by/2.0), which permits unrestricted use, distribution, and reproduction in any medium, provided the original work is properly cited.
} 


\section{Introduction}

Migration is common to many agrarian societies, and it has attracted multiple theories and explanations over the years (Brettell \& Hollifield, 2014). The recent spur in the scholastic engagements with migration is a result of economic globalisation (Lindquist, Xiang, \& Yeoh, 2012), which has created newer and diverse job markets for the migrants of developing nations. Although the spatial dimension of migration has long been a central theme of research (Ravenstein, 1985), the relative choice of a destination over others has not been duly addressed, especially for individual and recursive male outmigration. Since globalisation is stretching the boundary of migration from regional/national to diverse global destinations, it is crucial to understand the context in which a destination is chosen over another. It helps us understand where the workforce from agrarian societies of developing nations does end up and what factors do shape such decision-making.

India is one of the major participants in the international labour market and the inflow of remittance, in terms of foreign exchange alone, has impacted local livelihoods and national development. Despite its negligible contribution to the national GDP, the volume of remittance inflow in India is highest in Asia (\$62.7 billion) (World Bank, 2018), which is far more than the foreign direct investment received per year (ILO, 2016). In India, remittances are generally used for household consumption to reduce the family poverty level, and human welfare and a $10 \%$ growth in remittance inflows could lead to a 1.7 $\%$ deterioration in the poverty ratio (United Nations Conference on Trade and Development, 2011; Roy, Singh, \& Roy, 2015). Therefore, the decision of moving to different destinations is vital because of the causal links between remittance and poverty reduction in rural areas. Also, this emphasis on the choice of destinations is vital from the theoretical point of view since it is simultaneously linked to the decision of migration and the amount of remittance (because of the nature of industry/job market at the destinations). This link affects the lives of migrant families and communities.

According to the levels of focus, theories of migration can be of micro or macro in scope. While the micro-theories focus on the individual or household decision-making, the macro theories look at the trend of migration and explain them by macro-level factors. When the essence of macro models lies in the analysis of the broader perspective of migration process including the determinant factors, the goal of micro models is the analysis of the decisionmaking process regarding 'whether to move/not', 'where to move', and the factors associated with them. . The theorisation of migration has so far addressed the issues of the origin of migration, its directionality and continuity, the engagement of migrant labours, and their adaptations at destinations (Portes, 1997). Our study addresses the directionality and continuity of the migration process and tries to understand the associated determinants - a clear case of micro-level study.

There are theories that directly or indirectly explain the phenomenon of migration with special reference to the act of migration and choice of destination. The Neoclassical theories hold the centrality of actual wage differentials across markets or countries as the primary shaper of migration (Harris \& Todaro, 1970). In the related literature, we find both 'push' factors (such as low wages and high unemployment at origin) and 'pull' factors (such as the chronic and unavoidable need of workforces at destinations) explaining rural-urban movement (Harris \& Todaro, 1970; Stark, 1991). Another explanation involves the idea of 'growth pull', in which the destination promises better achievement and progress in terms of earnings (Islam, 1996) and/or the 'crowding out' when there is saturation in labour supply from an inadequate local economic prospect (Deshingkar, 2004). Besides these, the 'dual economy model' posits that migrants voluntarily select their market in search of higher income (Mosse et al., 2002). The Marxian interpretation justifies migration as a movement of rural poor out due to the 
exploitation of dominant classes (de Haan \& Rogaly, 2002). Moreover, the 'Neo-Malthusian' explanation employs multiple clarifications such as ecological stress, diminishing scope in the agricultural sector, debt cycle, overpopulation, degradation of natural resources, among others (Deshingkar, 2008).

The Human capital theory is one of several adjustments made to the neoclassical framework. It incorporates the sociodemographic characteristics of the individual as the determinants of migration (Bauer \& Zimmerman, 1999). Behavioural models, on the other hand, explain the non-economic aspects of migration, such as values (de Jong \& Fawcett, 1981). The New Economics of Labour Migration (NELM), developed in the 1990s, posits that labour migration is an approach to reduce household risk, increase income and overcome the limitations created by market imperfection (de Haan, 1999). As a unit of decision making, family or household shares both the rewards and costs of migration.

Historical-structural approaches to migration expound that the determinants of migration are related to the structural change in world markets, precisely a function of globalisation, transforming economies, and new forms of production (Massey et al., 1993). Neoliberalism has made sense of open markets, open trading and entrepreneurial activities, accomplished and propagated through law and social and economic policies that facilitate the citizens as sensible economic players in all domains of life (Brown, 2006). The market works to attain the strategic interests of employers globally by creating new job opportunities based on the commercialisation of labour, modern technologies, and facilities that encourages labour flows (Pieke \& Biao, 2009). Hence, due to the growing economic interdependence between countries in the world, the phenomenon of migration has increased significantly (Ganguly-Scrase, 2003).

Another group of researchers tries to explain the migration by the associated social network (de Haas, 2010). Network theory and Migration Systems theory describe and explain the nature, magnitude, destinations and the driving forces of migration. The network is a self-determining system, which reduces the cost and risk of enlarging the physical and psychological support of migrants at the destination and facilitates matching between newcomers and employers. Such benefits may, in turn, increase the probability of the migrant's decision to make a voyage to that particular place and further enlarge the networks. After reaching a certain level, the networks would be self-sufficient to eventually propagate migration without outstanding economic imperatives (Fawcett, 1989). Also, the 'labour chains', developed and sustained by labour contractors, hold the key to the steady support of labour migration in the globalised economy (Barrientos, 2013; Phillips, 2011).

However, it will not be out of context to touch upon the recent migration crises of Europe and the America that demands alternative paradigms of explanation. Although there is a trend of the discursive construction of the enemy (Balica \& Marinescu, 2018), critical discourse analysis goes beyond the social and economic parlance of migration. It envisages the broader political context of the crises. It moves ahead of the analytical and practical aspect and scrutinises the political (e.g. border control) policies to explain the crises (Pallister-Wilkins, 2016) along with the appreciation of the root causes such as war, persecution, and chronic poverty (Fernando \& Giordano, 2016). Although such developments are not directly linked to the current research problem, we mention these current developments for making the review exhaustive and letting the readers introduce to these evolutions in the literature.

The root of many physical aspects of migration is inherited from Ravenstein's work (1885), which Tobler (1995) reinterpreted in the light of 'currents' (of migration over physical spaces). Later, the choice of destinations, within the context of micro-level models, has been studied for the USA (Gimpel, 1999) and Europe (Crawley et al., 2016). The commonly cited external determinants are policy environment, nearness to borders, and tradition of migration in a region 
(Zuniga \& Hernandez-Leon, 2005), while the external determinants are income differentials, distance, population density, social proximity, and amenities (Fafchamps \& Shilpi, 2008). Also, we find wages and moving costs to influence the choice of destinations (Berger \& Blomquist, 1992). However, the majority of the studies deal with macro-level factors falling outside the scope of household-level decision-making and leaves room for micro-level factors influencing the choice of destinations. Although the culture of migration is reported to have an overarching influence on the selection of destination (Ali, 2007), the rapid changes in opportunities abroad offer newer challenges to researchers and need further explanations. Another group of studies explains the choice of destinations based on the concept of relative deprivation (Hyll \& Schneider, 2014), with only a few reports in the Indian context (Czaika, 2012). Such reports are even less available for the individual male migrants who leave their family back home to reach preferred destinations.

In summary, the existing literature has explained the micro and macro contexts of migration, the associated process of decision-making and the importance of social networks in supporting the human movement. However, it is not known - or reported clearly - how the choice of destination is shaped by different micro-level factors for individual and recursive male migrants. With increased urbanisation, industrialisation, and open labour markets, the range of destination is becoming diverse and emergent in nature, and this gap in the literature must be addressed to understand the complexity of migration in today's agrarian societies.

The present research was taken up to understand the diverse destinations of migration from selected regions of the Indian Sundarbans and to examine the determinants of their choices of destinations. We describe the inland and transnational migration from coastal West Bengal (an Indian state) and then study the chronology of the destinations pursued by the same migrants. Finally, using correspondence analysis, we examine the association of different factors with the diverse destinations of migration.

\section{Methodology}

The study was approved by the members of the ethical committee of the Integrated Rural Development and Management Faculty Centre of the Ramakrishna Mission Vivekananda Educational and Research Institute and approved in the Academic Council (Meeting No. 15 dated 24 August 2015) which takes care of the institutional reviews of all the academic and funded research projects at the Faculty Centre. The study followed a mixed-method approach, often used in migration research. The preference of methodology depends on the nature of the research problem and the type of research questions to be answered. Tashakkori and Teddlie (2010) proposed that a mixed-method research approach should be a link between concept-oriented issues and method-oriented issues or be the point of integration of these two. Yin (2006) viewed that the integration of research questions often permitted the process and outcome of the same substantive issue to be identified by each method (quantitative and qualitative). The employment of mixed method for a single research problem does not only mean to collect numeric data and narrative data. The researchers collected both quantitative and qualitative data, analysed both the data sets separately, compared the results from the analysis of separate data sets, and made interpretation in support or contradiction of each other's results (Creswell, 2012). Research on migration has often been framed within a quantitative-qualitative continuum; the reason may be that migration studies envisage both causalities and life experiences of people. While quantitative approaches employed a questionnaire survey using pre-determined frameworks, the qualitative approaches used focus groups and in-depth interviews to arrive at theoretical categories (Rose, 2001).

\section{Sampling}

Sunderbans, the largest deltaic region in the world, is located in the coastal region of West Bengal. It is rich in biodiversity with substantial forest cover, and the inhabitants of this region 
largely depend on non-timber forest products (NTFPs), mono-cropped agriculture and fishing as means of livelihoods. People managed to live under critical climatic stress such as flood, cyclonic storms and raised water level that threatens to breach river embankments of the islands and inundate the farmlands and dwellings. Besides, due to the low absorbing capacity of the competent workforce in monocropped agriculture, a significant portion of the workforce remains unemployed or underemployed. Declining profitability of agriculture, degradation of natural resources, and restrictive rules and regulations regarding the use of forest resources have led the youths of this region to diversify or transform their livelihoods, often resorting to some nonconventional livelihood activities (District Human Development Report: South 24 Parganas, 2009). Inadequacy of local infrastructure, government support services and household assets of smallholders or landless people make migration an inevitable livelihood strategy in coastal West Bengal (Mistri, 2013).
Two community development blocks, namely Namkhana and Sagar from the Sunderbans region, were taken up purposively for the study (Figure 1). Non-probability sampling was preferred to probability sampling because of its ability to identify the specific group of people who were the focus of this study (the migrants were concentrated in those blocks). Namkhana and Sagar Blocks are ranked 19th (HDI score 0.58 ) and 24th (HDI score 0.55 ) respectively in the district, in terms of their Human Development Index, representing their backwardness (District Human Development Report: South 24 Parganas, 2009). These blocks are adjacent to each other and consist of 7 and 9 Gram Panchayats (GP) respectively. Sagar, an isolated island, is situated at the extreme south of West Bengal state. Study areas (Dakshin Chandranagar village of Namkhana Block and Shibpur village of Sagar Block) were selected because of the high incidence of migration there, as suggested by the Government officials, Panchayat Pradhans (head of the village governance), Panchayat members, and local NGOs.

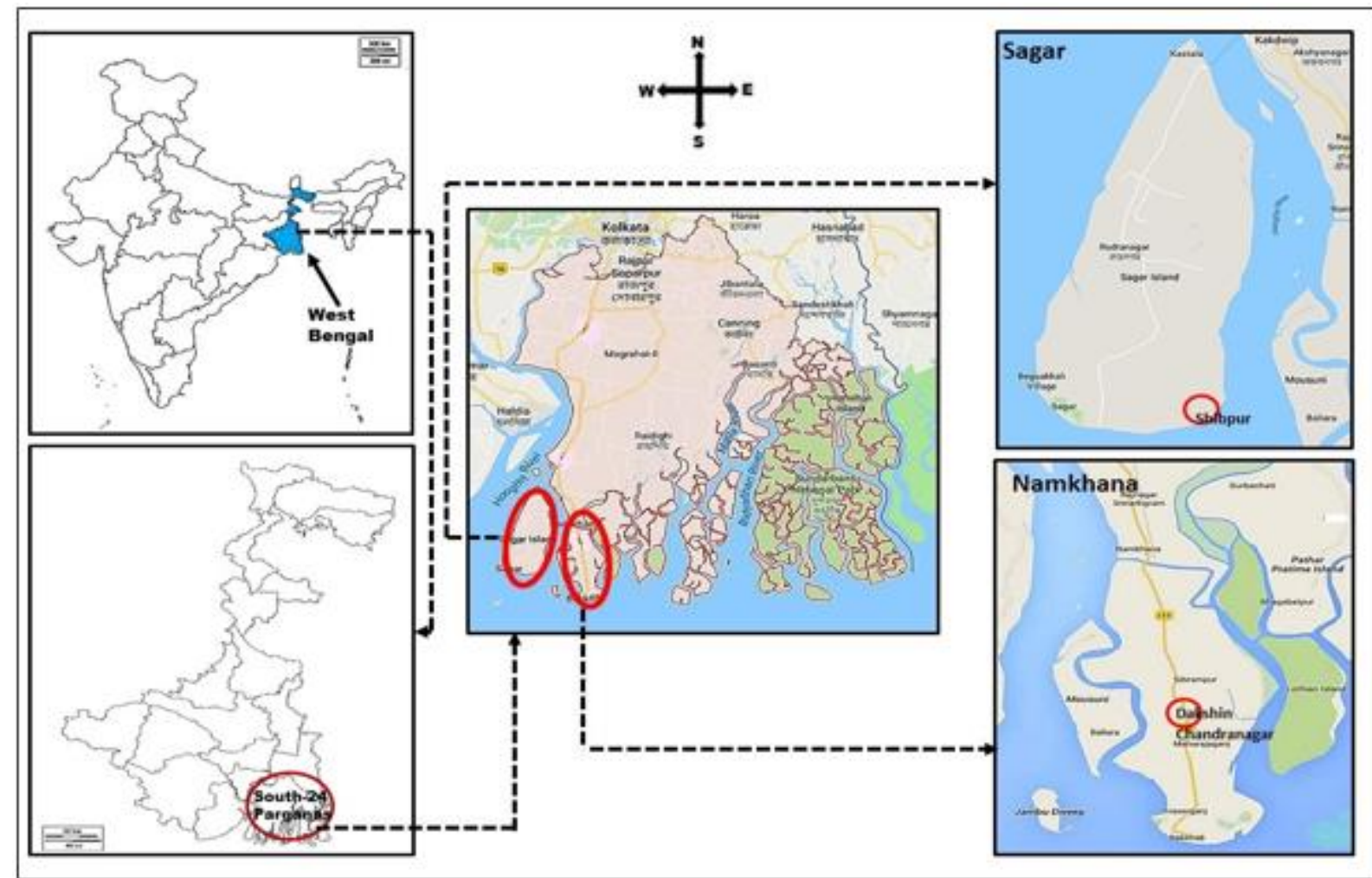

Figure 1: The study Locations under South 24 Parganas District of West Bengal State, India. Study Blocks are encircled Source: Authors 
The villages studied are located far away from the city of Kolkata. Dakshin Chandranagar village, situated in the southern part of Namkhana, is $109 \mathrm{~km}$ away from Kolkata and 16 $\mathrm{km}$ away from Bakkhali (a popular tourist place). Shibpur village, located at the southern tip of the Sagar Block near the Bay of Bengal. This village is $116 \mathrm{~km}$ away from Kolkata and situated near Gangasagar, a holy place for the Hindu pilgrims. Though Shibpur is hugely challenged by environmental vulnerabilities (enormously affected by cyclone Aila in 2009), both the areas are partially dependent on agriculture as a means of livelihood, have poor infrastructure and offer little scope for local employment. Survey data were collected from 206 households, having at least one national or international migrant in the family, by total enumeration of two and three randomly selected settlements of Dakshin Chandranagar and Shibpur villages respectively.

\section{Data}

Quantitative data were collected in a face-toface situation with a pre-tested semi-structured interview schedule. Informed consent was taken from all the respondents before the interviews. The objectives of the study, along with the rights of the respondents were read out clearly before the informed consent form was signed/verbal consent recorded. The interview schedule consisted of sections such as socio-demographic information, household assets, migration (destinations, nature of work, duration, etc.) and its reasons, and remittance and its utilisation. The interviews were supplemented by in-depth interviews, key informant interviews and focus group discussions with checklist and Participatory Rural Appraisal (timeline and mobility mapping). In each village, before starting the interview, several days were spent to establish rapport with the villagers. The schedule was administered to the respondents, and the first author herself recorded responses. The data were collected during two consecutive winter seasons, that is, December 2015 to March 2016 and November 2016 to February 2017 from the villages of Namkhana and Sagar respectively. Key informant interviews were conducted with
Panchayat functionaries, local NGO staffs and government officials at their workplaces. The indepth interviews were carried out at the dwelling places of the interviewees. The researcher facilitated the focus group discussions and PRA with the villagers as per their convenient time and place. All the qualitative data were audio recorded by the researcher; descriptive field notes were recorded throughout the study.

Survey data were screened and analysed by SPSS 20 for Windows (IBM SPSS statistics 20.0. SPSS Inc., Chicago, IL, USA.). For a better understanding of the relationship between the categories of six factors and the destinations of migration, correspondence analysis (CA) was used. In the bivariate condition, one variable was the destinations of migration (each destination being a category), while the others were chronology of migration (the first/second/third/fourth/fifth/sixth incidence of migration by an individual), education of the migrant

(illiterate/primary/middle/secondary/higher secondary/college), age (early adulthood/midlife/mature adulthood), amount of remittance $(<28817 / 28818-89,167 / 89168$ $149518 />149518)$, the reason of migration (household needs/asset creation/profession/lump sum money/others), and type of job at destinations (pipeline labour/load and unload/concrete road making/helper/trawler driver/construction labour/others). A bivariate CA characterises the row or column variables (Thompson, 1995). A structural relationship can be established by providing a joint graphical display of variable categories that would not be detected in a series of pairwise comparisons of variables (Hoffman \& Franke, 1986). CA also helps to show how variables are related, not just showing that the relationship exists between a factor and the destination of migration. Although CA has rarely been used in migration studies (Ozden \& Mendes, 2005), we found it appropriate for understanding the relationship between 'the decisions of selecting the destination' and 'its associated determinants'. Because, even if the bivariate relationship was not significant 
statistically (e.g. in chi-square tests), we could still explore the association of categories of factors with the choice of destinations. On the other hand, the qualitative data were organised, coded, and developed into themes, representing the findings recorded as narratives and visuals. Data from one source was triangulated, supplemented and complemented by other sources for understanding the complexity of migration in the study areas. These were then combined for describing study objectives and elaborating its interpretations.

\section{Results and Discussion}

\section{Context of Migration in the Study Areas}

Different contexts of migration were observed in the two studied villages. Dakshin Chandranagar in Namkhana Block was economically backward, encouraging occasional migration of a few villagers (initially) within the West Bengal state. Household food security could not be maintained by agricultural production alone, and recurrent crop failure due to climatic vagaries during the late 1980s forced a portion of the male members to migrate to Kerala, Mumbai, Gujarat, Orissa, and other places. Since the 1990s, villagers started moving across the world, and at the time of data collection for this study, migration had already become the prime means of sustaining the community's livelihoods. In fact, villagers found migration to be more natural and rewarding than increasing agricultural production by an improved variety or other modern technology of cultivation.

An agent, who facilitated migration to distant places through logistic supports said:

20-25 years ago two or four villagers from here went to Mumbai and realised that a journey could be made abroad from there...first, they went to Gulf Countries...after that, they took other villagers with them...this way, they maintained the supply of labour to different overseas areas

Shibpur village, due to its closeness to the river, is extremely vulnerable to natural disasters and was one of the devastated areas in Sagar Block during cyclone Aila in 2009. Agriculture, the backbone of the village, was almost ruined as the cultivated lands were inundated by saline water. The villagers could not save their houses from the gradual grab of the Bay of Bengal, and the only perceived coping strategy was the migration of male members of the family. A timeline of migration showed that both the villages had a long history of migration; however, villagers of Dakshin Chandranagar started moving outside the country nearly three decades ago and sustained the trend with the logistic supports from the local labour agents. On the other hand, villagers of Shibpur mostly migrated within the country, which spurred after the natural disaster Aila in 2009 (Table 1).

The process of migration is usually shaped by a multifaceted set of push and pull forces (Warner, Hamza, Oliver-Smith, Renaud, \& Julca, 2010). To serve the basic human needs and to enhance the resilience against weather abnormalities, male members from both the areas moved out to both inside and outside the state of West Bengal. Male members from the riparian settlements in Shibpur started to migrate frequently while an incremental and cautious migration was recorded in Chandranagar. It suggests that both opportunistic considerations and climatic distress played a role in migration, although they had differential contexts and trajectory of development. The destinations differed since the historical trajectory of migration in these two villages were different. While poverty, abiotic stress of agriculture, lack of local opportunity and the emergence of 'agent' (labour agents facilitating villagers to distant locations) was pivotal in Chandranagar, climatic extreme was the prime factor of migration in Shibpur. We will come back to this point later in this study.

\section{Mobility of the Migrants}

The mobility map of the migrants, synthesised from the outcomes of PRA tools and FGDs, provided comprehensive qualitative information about the destination, job types, and terms and conditions of employment (Table 2, Figure 2). 


\begin{tabular}{|c|c|c|c|}
\hline & $\begin{array}{l}\text { Dakshin Chandranagar, Namakhana } \\
\text { Block }\end{array}$ & & Shibpur, Sagar Block \\
\hline 1968 & $\begin{array}{l}\text { Villagers traveled to Hooghly, Howrah, } \\
\text { Medinipur (districts within the West } \\
\text { Bengal state of India) as casual labours }\end{array}$ & 1970 & $\begin{array}{l}\text { Traveled to Hooghly, Howrah, } \\
\text { Medinipur and Bardhaman to work } \\
\text { in potato cold stores, rice mills and } \\
\text { to work as casual labours }\end{array}$ \\
\hline 1984 & $\begin{array}{l}\text { Went to Haldia for working at Oil and } \\
\text { Natural Gas Commission (ONGC) sites as } \\
\text { pipeline fitter; to Bardhaman for working } \\
\text { in potato cold stores }\end{array}$ & 2000 & $\begin{array}{l}\text { Went to Haldia to work at ONGC } \\
\text { sites }\end{array}$ \\
\hline 1988 & $\begin{array}{l}\text { Worked as labour of pipeline and } \\
\text { construction of building in Gujarat, } \\
\text { Mumbai, Kerala (states of India) }\end{array}$ & 2005 & $\begin{array}{l}\text { Started traveling to Kerala, Gujarat, } \\
\text { Orissa to work as construction } \\
\text { labours and other casual labours }\end{array}$ \\
\hline 1990 & $\begin{array}{l}\text { Four to five persons went to the } \\
\text { Kingdom of Saudi Arabia and set the } \\
\text { trend of migration to different Gulf } \\
\text { Countries }\end{array}$ & 2009 & $\begin{array}{l}\text { Increased tendency of migration to } \\
\text { Kerala after Aila (2009) }\end{array}$ \\
\hline 1993 & $\begin{array}{l}\text { One person started working as an agent } \\
\text { who 'sends the youth' to 'aboard' }\end{array}$ & & \\
\hline 2005 & $\begin{array}{l}\text { Started moving to Singapore and other } \\
\text { South-East Asian countries }\end{array}$ & & \\
\hline 2015 & Started migrating to Russia and Tanzania & & \\
\hline
\end{tabular}




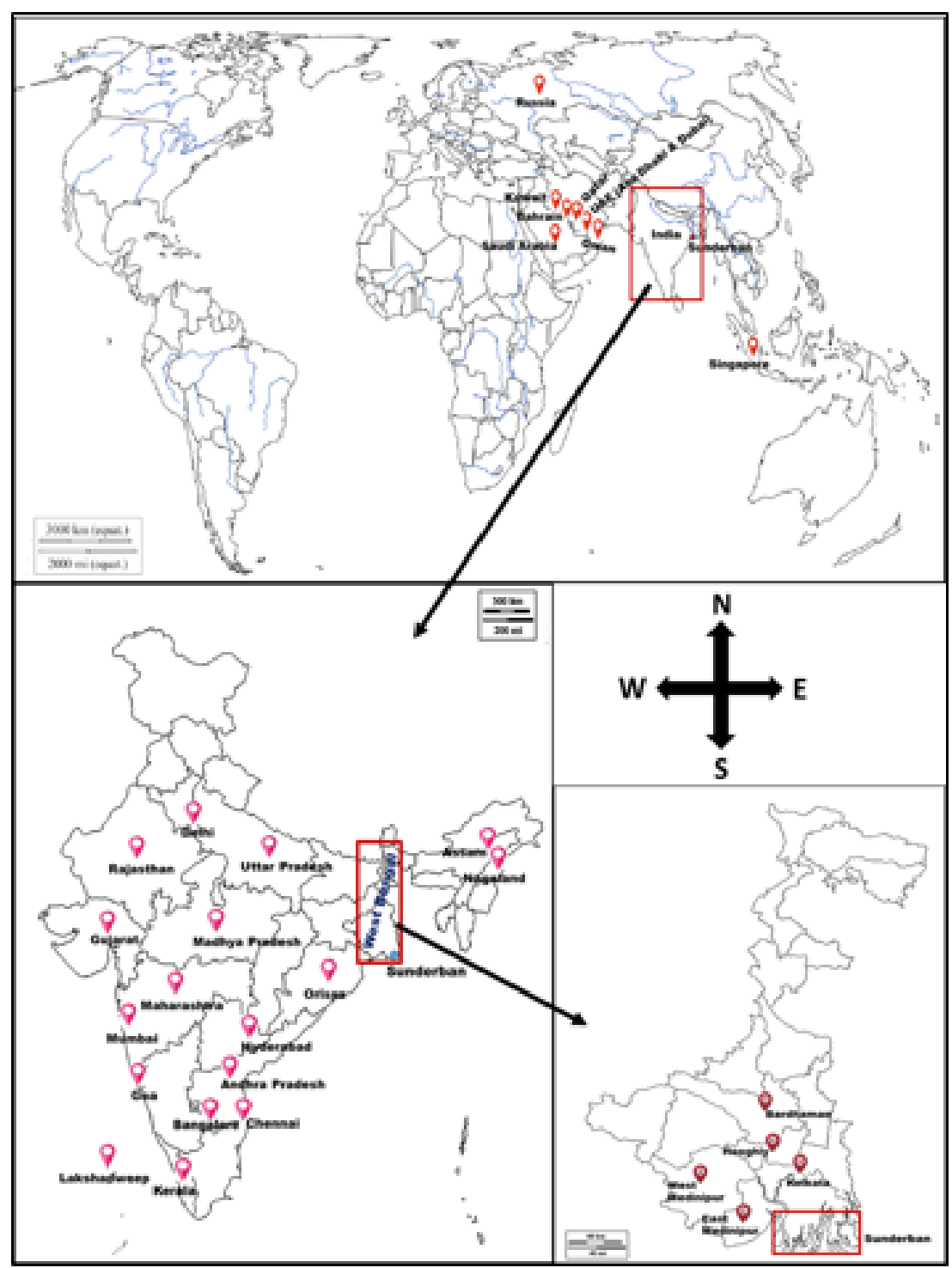

Figure 2: Destinations of Migration from the Study Areas

Source: Authors 


\begin{tabular}{|c|c|c|c|}
\hline $\begin{array}{l}\text { Name of the } \\
\text { places }\end{array}$ & Type of job & Terms and Conditions & Durations \\
\hline Gulf Countries & \multirow[t]{6}{*}{$\begin{array}{l}\text { - } \text { Pipeline fitter } \\
\text { - } \text { Helper } \\
\text { Cuilding } \\
\text { Construction }\end{array}$} & $\begin{array}{l}\text { INR 15-20 thousand/ per } \\
\text { month } \\
\text { - Food and Lodge } \\
\text { - Free medical treatment } \\
\text { - Travelling fare for returning } \\
\text { home } \\
\text { - No work no pay } \\
\text { - Overtime pay }\end{array}$ & \multirow[t]{6}{*}{$\begin{array}{ll}\text { - } & \text { Six months } \\
\text { - } & \text { One year } \\
\text { - } & \text { More than } \\
\text { one year } \\
\text { (*as per } \\
\text { contract) }\end{array}$} \\
\hline Indonesia & & $\begin{array}{l}\text { INR } 20-25 \text { thousand per month } \\
\text { (other facilities - same as above) }\end{array}$ & \\
\hline Malaysia & & \multirow{2}{*}{$\begin{array}{l}\text { INR } 30-50 \text { thousand per month } \\
\text { (other facilities - same as above) }\end{array}$} & \\
\hline Singapore & & & \\
\hline Russia & & $\begin{array}{l}\text { INR } 25-30 \text { thousand per month } \\
\text { (other facilities - same as above) }\end{array}$ & \\
\hline Tanzania & & $\begin{array}{l}\text { INR } 35-40 \text { thousand per month } \\
\text { (other facilities - same as above) }\end{array}$ & \\
\hline Kerala & \multirow{6}{*}{$\begin{array}{l}\text { Building } \\
\text { Construction } \\
\text { - Pipeline fitter }\end{array}$} & \multirow{7}{*}{$\begin{array}{l}\text { INR 10-15 thousand per } \\
\text { month } \\
\text { - Free lodge in some cases }\end{array}$} & \multirow{7}{*}{$\begin{array}{l}\text { As and when } \\
\text { required }\end{array}$} \\
\hline Gujarat & & & \\
\hline Tamil Nadu & & & \\
\hline Mumbai & & & \\
\hline Hyderabad & & & \\
\hline Chennai & & & \\
\hline Orissa & $\begin{array}{ll}\text { - } & \text { Building } \\
\text { Construction } \\
\text { - } \\
\text { Casual Labour } \\
\end{array}$ & & \\
\hline Hooghly & \multirow{2}{*}{$\begin{array}{l}\text { Load and unload } \\
\text { work at potato and } \\
\text { rice mill }\end{array}$} & \multirow[t]{4}{*}{ Rs. 6-7 thousand per month } & \multirow{4}{*}{$\begin{array}{l}20-25 \text { days } \\
\text { As and when } \\
\text { required }\end{array}$} \\
\hline Bardhhaman & & & \\
\hline Howrah & \multirow[t]{2}{*}{ Casual Labour } & & \\
\hline Medinipur & & & \\
\hline Source: Authors & & & \\
\hline
\end{tabular}


Migration to Hooghly, Bardhaman, Howrah, and Medinipur occurred mostly for the performance of casual labour works such as loading and unloading in potato stores and rice mills, and other short-term manual works for 20-25 days. Such migrations took place when the families were in pressing need of cash income and their wage, on an average, ranged from INR 6,000 to INR7,000 in a single stint. The migrants who moved outside West Bengal (that is, those who moved to Kerala, Gujarat, Tamil Nadu, Mumbai, Hyderabad, Chennai, and Orissa) earned INR 10,000-15,000 per month depending on the nature of the work. Works in those locations included building construction, pipeline fitting, and other casual forms of labour. They could come back home as and when they wanted to and could avail of free lodging facilities from their employers. Gradually, the periphery of migration extended beyond India to the overseas locations of 'oil-rich' Gulf countries, Indonesia, Malaysia, Singapore, Russia, and Tanzania, where they mostly worked as pipeline fitters. In short, more than two-thirds of the migrants (70.4\%) migrated outside the state of West Bengal (but within India), followed by overseas $(23.3 \%)$ and intrastate (within West Bengal state) migration (6.3\%) (Table 3). The employers were responsible for providing the migrants with some amenities as part of the fixed-term contract such as free food and lodge, medical treatment, the travelling fare for returning home, and payment for 'overtime'. These amenities were available in addition to the monthly average earnings. The amount ranged from INR15,000-20,000 in the case of Gulf Countries and INR20,000-40,000 for other countries. They could only come back to their home when released by their employers temporarily or permanently at the termination of the contract, which varied from six months to a few years. Literature suggests diverse arrangements and working conditions of migrant labours, which, along with the context of migration at the source, determines the destination of migration (Greenwood, 1997). However, despite unacceptable and exploitative working conditions at some destinations, migrants might not have a choice of selecting destinations (Wahba, 2014). Such exploitation existed partially due to the ad-hoc and abrupt emergence of opportunity without having sufficient time and agency to check on the ground realities. Also, some migrants had an uncontrolled aspirational drive to go abroad, which was limited among the educated workforce (Brown, Scrase, \& Ganguly-Scrase, 2017).

\section{Table 3: Distribution of Migrants According to the Destinations}

\begin{tabular}{|l|c|}
\hline Destination & Frequency (\%) \\
\hline Transnational (overseas) & $48(23.3)$ \\
\hline In India (internal) & $145(70.4)$ \\
\hline In West Bengal (local) & $13(6.3)$ \\
\hline & Total $\mathbf{N = 2 0 6}$ \\
\hline
\end{tabular}

In Dakshin Chandranagar village, a strong and active network of labour outflow for transnational migration was developed and regulated by some 'agents'. The agents usually received INR70,000 to INR1,25,000 from migrants for facilitating their international voyage. The amount depended on the destination and the nature of the job, unlike the cases of inland migration. In the cases of migration within the state or India, migrants moved in a group or with their neighbours or relatives, who had already migrated. A key informant said:

In our village, there are a number of agents who communicate with the employers staying abroad and make all arrangements for sending labour from here...they facilitate passports and visas of young males...through the agents, 
men appear in interviews and travel abroad...the agents realised that they would earn more profit if they send more labours (abroad).

A network is a form of social asset, which is developed by human interaction with each other's trust, knowledge, and dignity of life. The networking system is responsible for the characterisation of migration in an area that facilitates migrants to access new opportunities in a new economic condition. Literature suggests that migrants also develop informal network/s with fellow workers at the destination (Knight, Thompson, \& Lever, 2017), which reduces vulnerability and broadens the psychological supports from peer groups. Social networks are crucial to migrants for finding jobs and accommodation, goods and services, as well as mental assistance and uninterrupted dissemination of social and economic information. The networks, used by skilled migrants for transnational migration, are often likely to be diverse and might have produced different livelihood outcomes than those used by low or unskilled migrants (Vertovec, 2002). The formation of formal or informal channels and their regulation of migration of male members, both in destination and origin, satisfies the theory of the said migration network system. An agent found such labour movement easier with his established networks:

That time I realised, sending of labours to Dubai, Qatar, Oman, Bahrain, Saudi Arabia, Singapore is straightforward... if I would make contacts with those areas through a person having a workforce license, I can send several people from here.

\section{Chronology of Choice of Destinations}

Figures 3a-3f describe how the destinations of migration changed over time for the same family or group of families. The figures describe the distribution of destinations when the migrants are moving out for the first/second/third/fourth/fifth/sixth times (please refer to Figures. 3a to $3 f$ ). The number of migrants and their number of destinations went down in the successive incidence of migration, indicating the discontinuance of migration by a proportion of villagers and funnelling the destinations down to a few remunerative (overseas) and logistically less constrained places (Kolkata, Medinipur). The first phase of destinations was predominantly within India, although overseas areas, especially the Gulf countries, were sometimes found to be the first destination of migration (Figure 3a). Kerala (47.3\%) was the most favourable destination within India, followed by Kolkata (10.2\%), Mumbai $(8.8 \%)$, Gujarat $(7.3 \%)$, and Orissa (4.4\%). Although Kerala (24.1\%), Gujarat (13.8\%), and Orissa (10.3\%) continued as the favoured destinations at the second phase, a portion of the migrants shifted from national to overseas destinations such as Saudi Arabia (11.5\%), Dubai (10.3\%), and Singapore (5.7\%) (Figure 3b). Kerala (17.9\%) and Mumbai (12.8) were still the popular national destinations while relative popularity of Gulf countries such as Saudi Arabia (15.4\%), Abu Dhabi (7.7\%), and Qatar (7.7\%) increased as the third destination (Figure 3c). While Kerala (31.6\%), Abu Dhabi (21.1\%), and Dubai (10.5\%) emerged most familiar as the fourth destination (Figure 3d), we find a mix of state, national, and international destinations at the fifth stage (Figure 3e). Only four overseas destinations were recorded at the sixth stage (Figure $3 \mathrm{f}$ ), and we abstain from any discussion on this because of their minimal frequency. We observe that the frequency at the later stages of migration decreased because a lesser number of migrants continued long-term and recurrent migration.

Moreover, the number of destinations decreased at the later stages because they might have found a stable and known place to work in at the destination and avoided any uncertainty associated with staying/working at a new place. Kerala was a place to offer steady jobs in the oil industry and construction sector (Zachariah \& Rajan, 2007) and many of the migrants recurrently went there for earning a better wage. Also, their familiarity with the place and presence of fellow workers from West Bengal gave them 'a sense of security' The journey to Gulf countries is an old tradition (De Haan, 2002) and the labour agents facilitated a seamless 
journey to those countries with the necessary logistical support. We could also find a transition from national to transnational migration and anticipate that the enhanced skill of migrants might have resulted in enhanced aspiration and opportunity. We will come back to this issue later in this study.

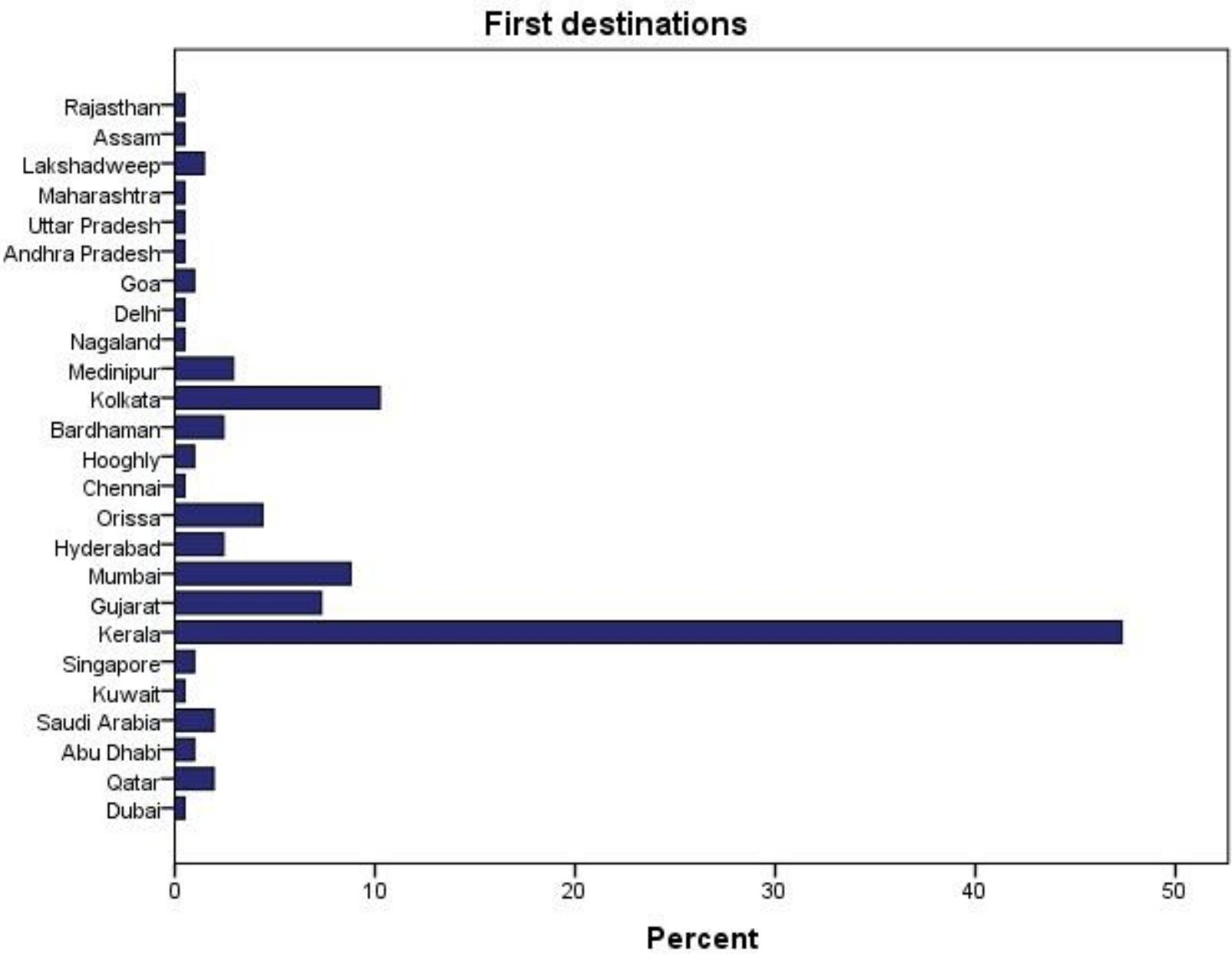

Figure 3a: First Migration Destinations $(n=205)$

Source: Authors 


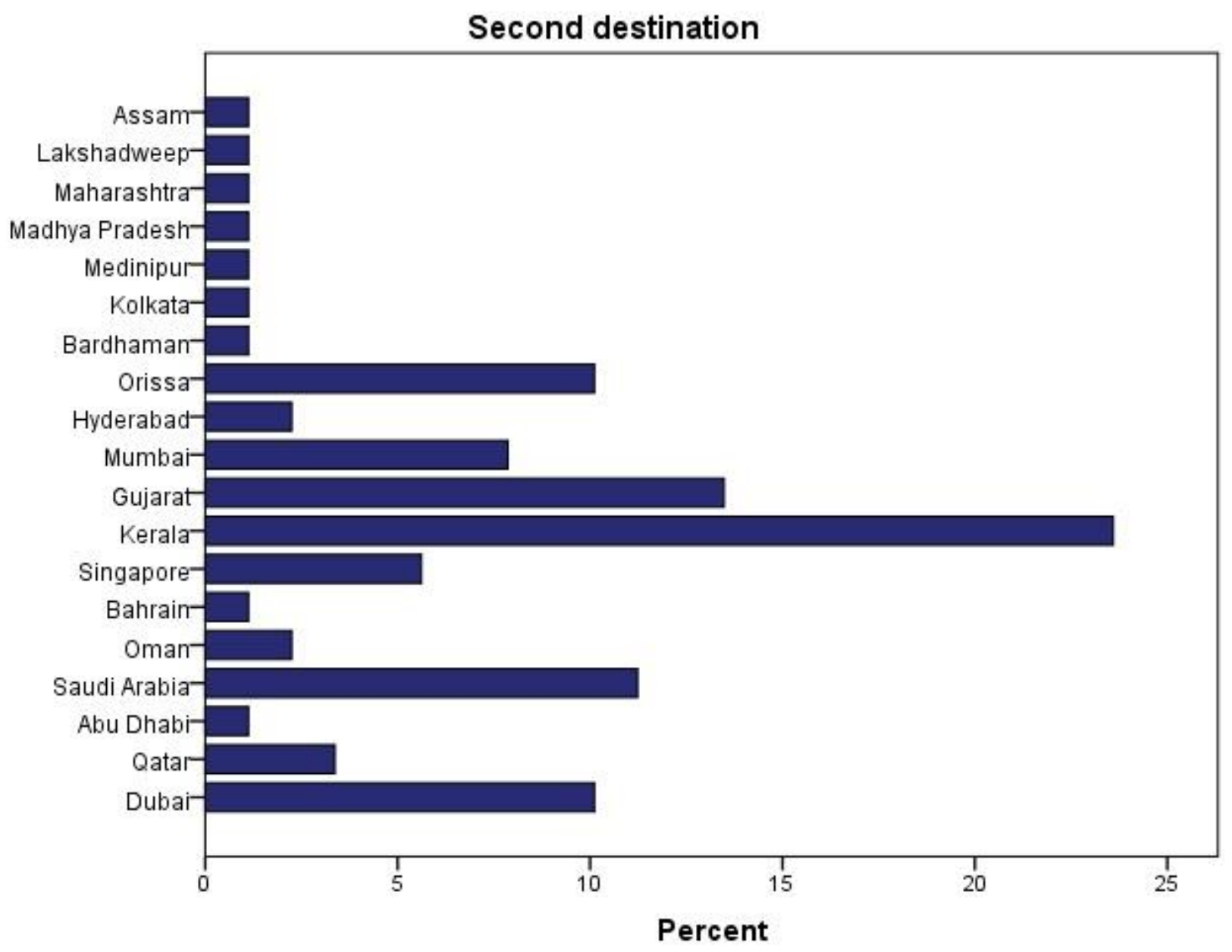

Figure 3b: Second Migration Destinations $(n=89)$

Source: Authors 
Third destinations

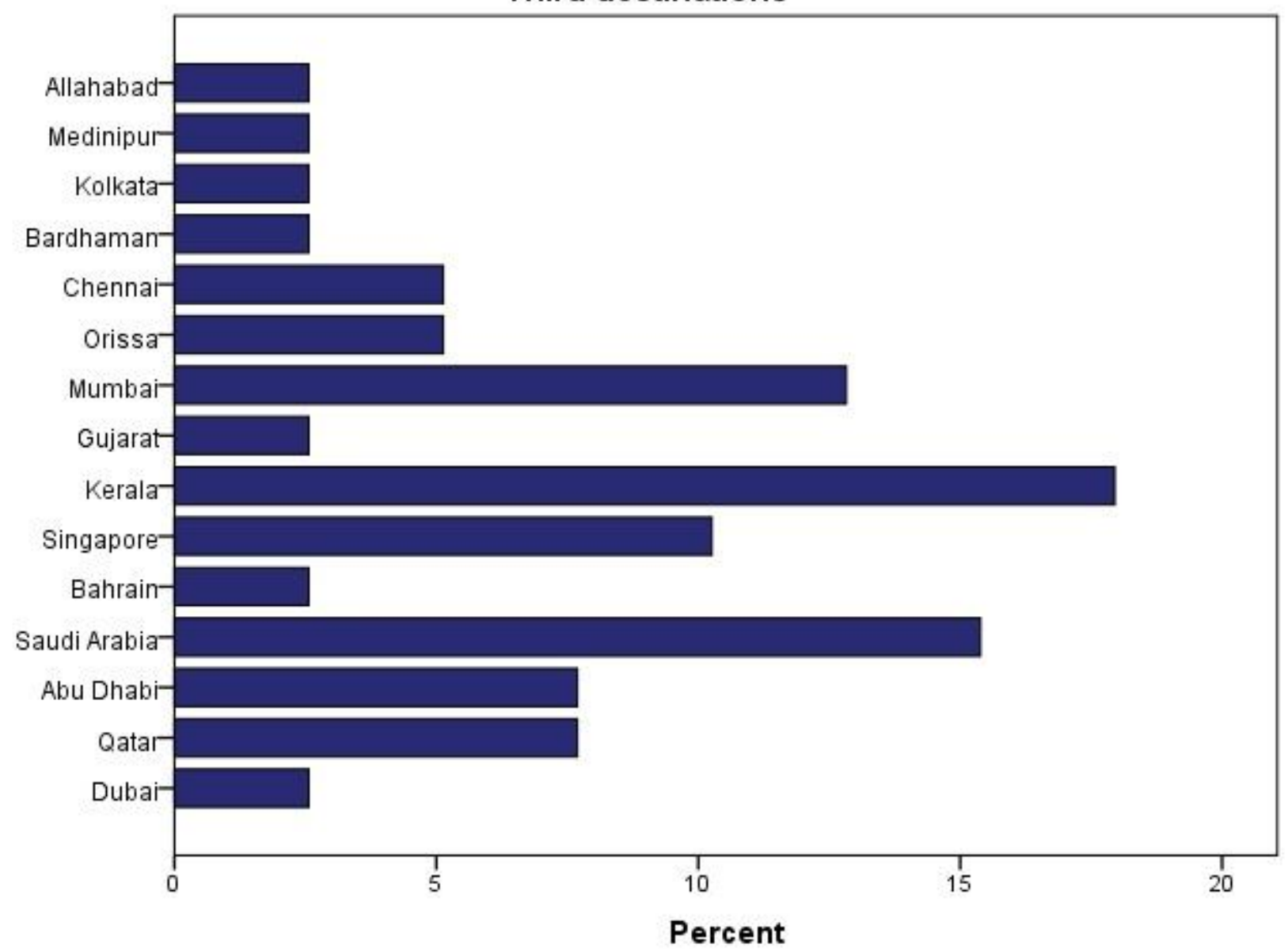

Figure 3c: Third Migration Destinations ( $n=39$ )

Source: Authors 


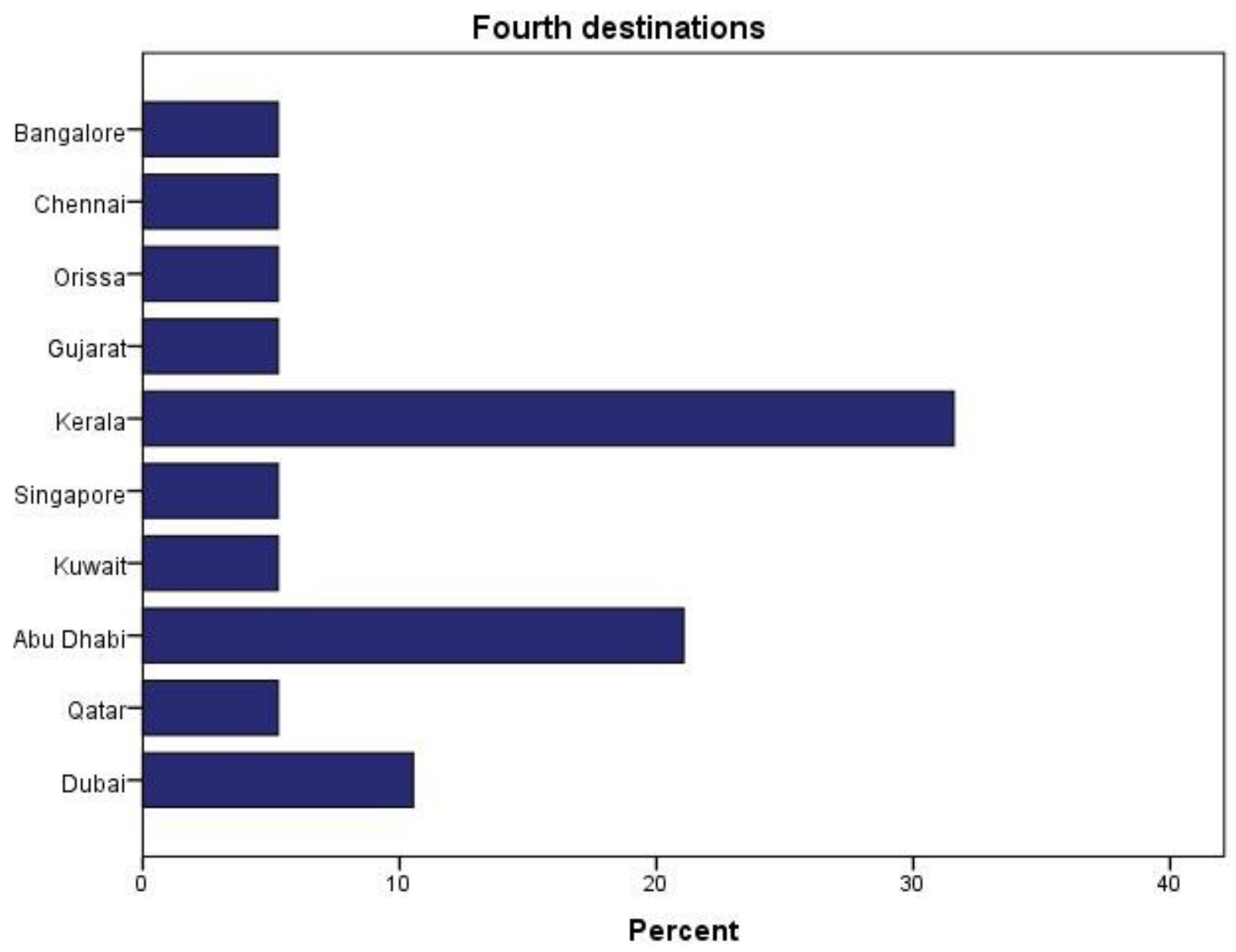

Figure 3d: Fourth Migration Destinations ( $n=19)$

Source: Authors 


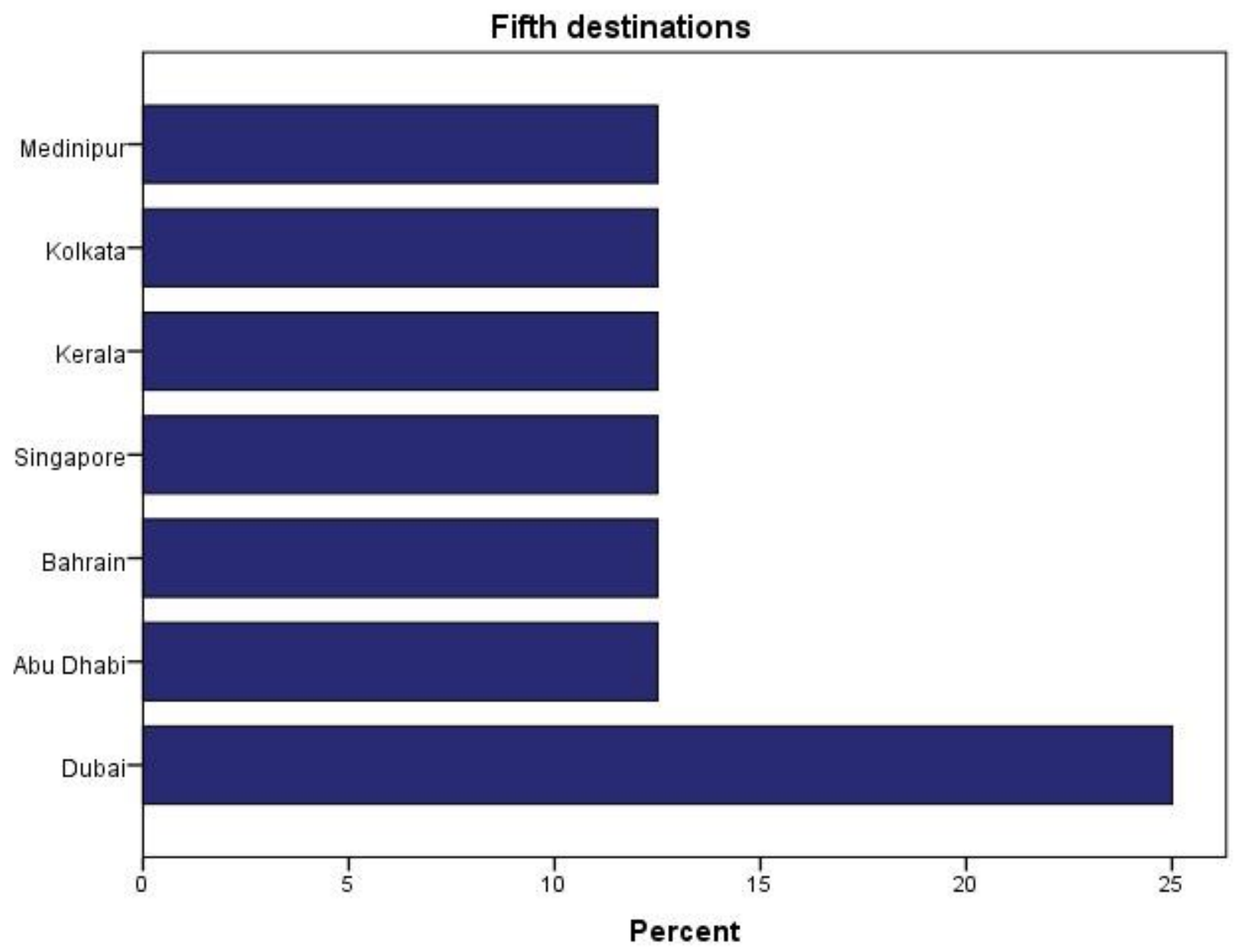

Figure 3e: Fifth Migration Destinations ( $n=8)$

Source: Authors 


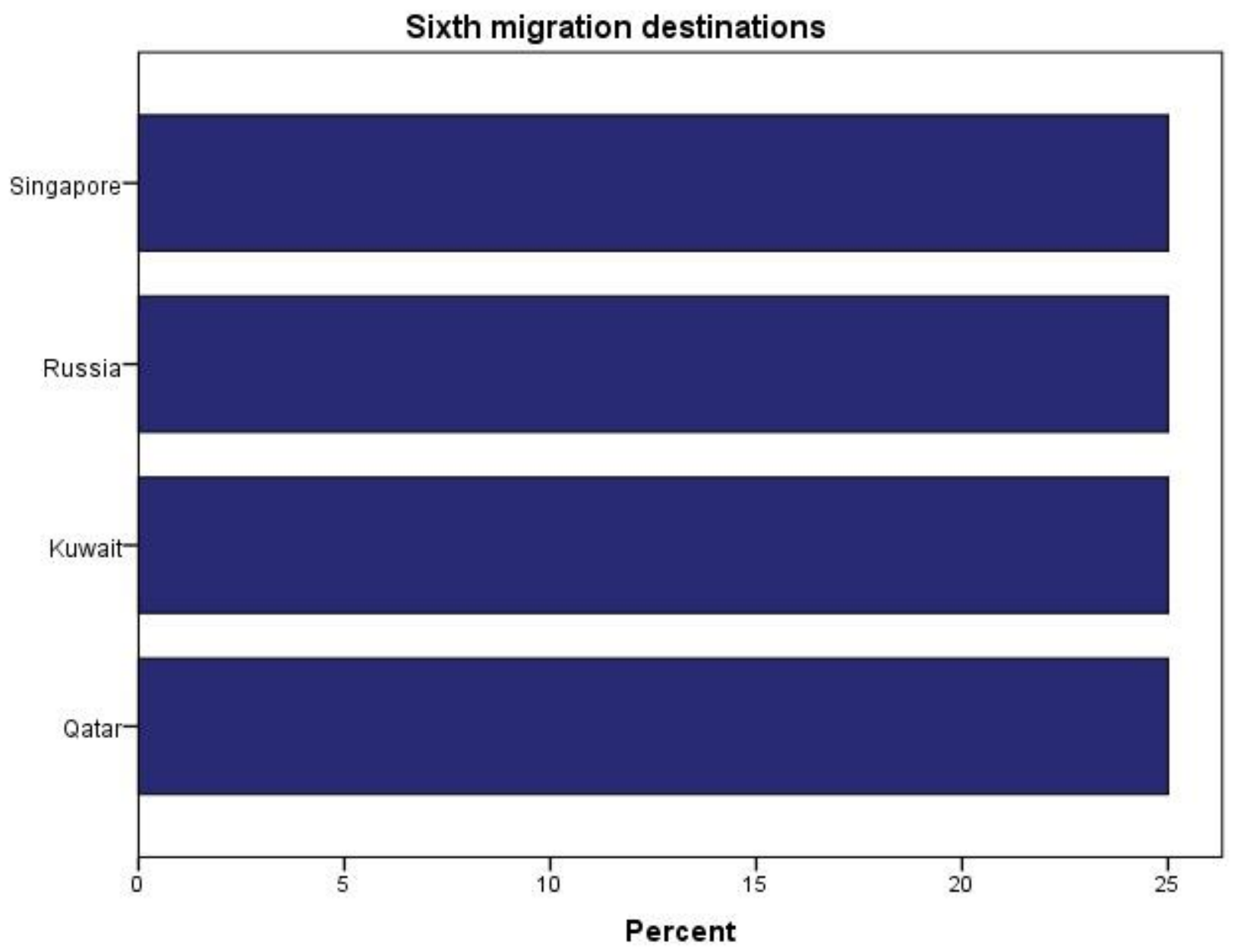

Figure 3f: Sixth Migration Destinations $(n=4)$

Source: Authors

\section{Determinants of a Selection of Destinations}

Figures $3 a-3 f$ describes the changes in the relative frequency of destinations in the context of recurrent migration. However, we were also interested to know what factors were associated with such a selection of destinations. Literature suggests a relationship between migration decision (to select destinations) and several personal and migration-related characteristics. These are topological, climatological, and environmental conditions that determine the kinds of jobs that a migrant is searching for employment. Other considerations, such as lifecycle, place, distance, equilibrium and disequilibrium perspective, employment status at the destination, regional unemployment, and recursive nature of migration of an individual influence the decisions on migration at the individual and family level (Greenwood, 1985; Fafchamps \& Shilpi, 2008). In this empirical study, we tried to establish relationships between the decision of choosing migration destinations with some personal characteristics such as migration chronology, educational level, and age of the migrants and some migrationrelated factors such as the expected amount of remittance, the reason for migration, and nature of the job. These factors were selected because they were operative at the micro-level and, thus, directly related to the conscious decision of choosing destinations.

The correspondence analyses have shown the column and row profiles in a single plot (Figures. $4 a, 4 b, 4 c, 4 d, 4 e .4 f)$, where the closeness of row and column profile points suggests a potential relationship. Please note that this is a combination of two independent plots where the distances between the row profile points and column profile points are not defined. Hence, the points visually shown closer in a two- 
dimensional space may not precisely represent their distances in higher dimensional spaces of the row and column plots. However, the points located closer and on the same side of the coordinate might give us a reasonable basis to associate one destination with one or the other categories of the six factors (variables) mentioned above and can be cross-checked with the table values (Table 4). However, the decision to choose a destination is a complex interplay of several factors such as skill level, family need, family type, caste, economic status, and availability of support network. We explain individual factors separately and discuss them in the light of such complex interplay of factors at the end of these individual discussions.
Row and Column Points

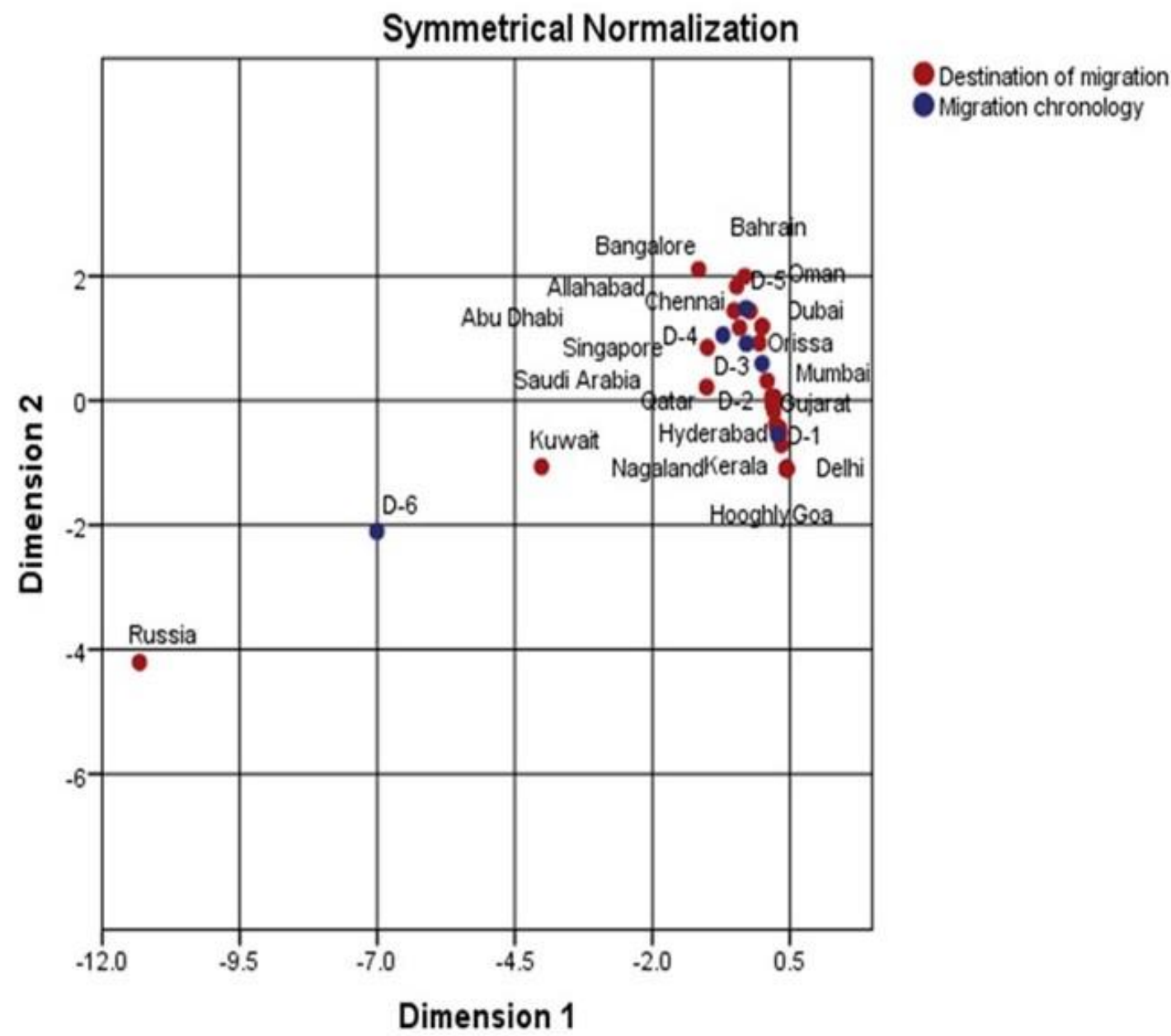

*Note: Chronology of migration, D1= First destination, D2 = Second destination, D3= Third destination, D4= Fourth destination, D5= Fifth destination, D6= Sixth destination

Figure 4a: Two Dimensional Correspondence Analysis of Migration Chronology and Destinations of Migration 


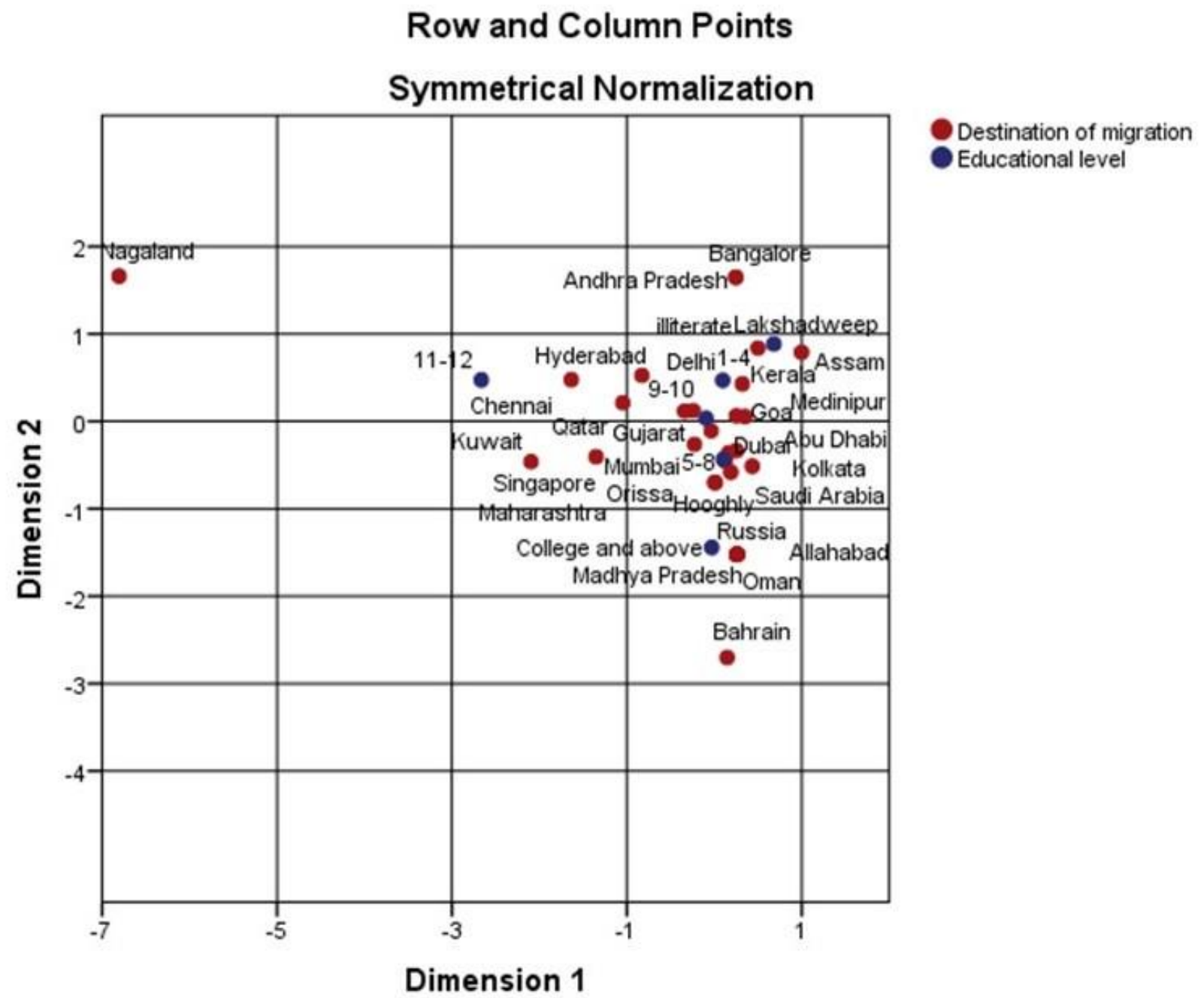

*Note: Educational levels, Illiterate, 1-4= primary, 5-8= middle, 9-10=secondary, 11-12= higher secondary, and college and above

Figure 4b: Two Dimensional Correspondence Analysis of Educational Levels of the Migrant and Destinations of Migration 


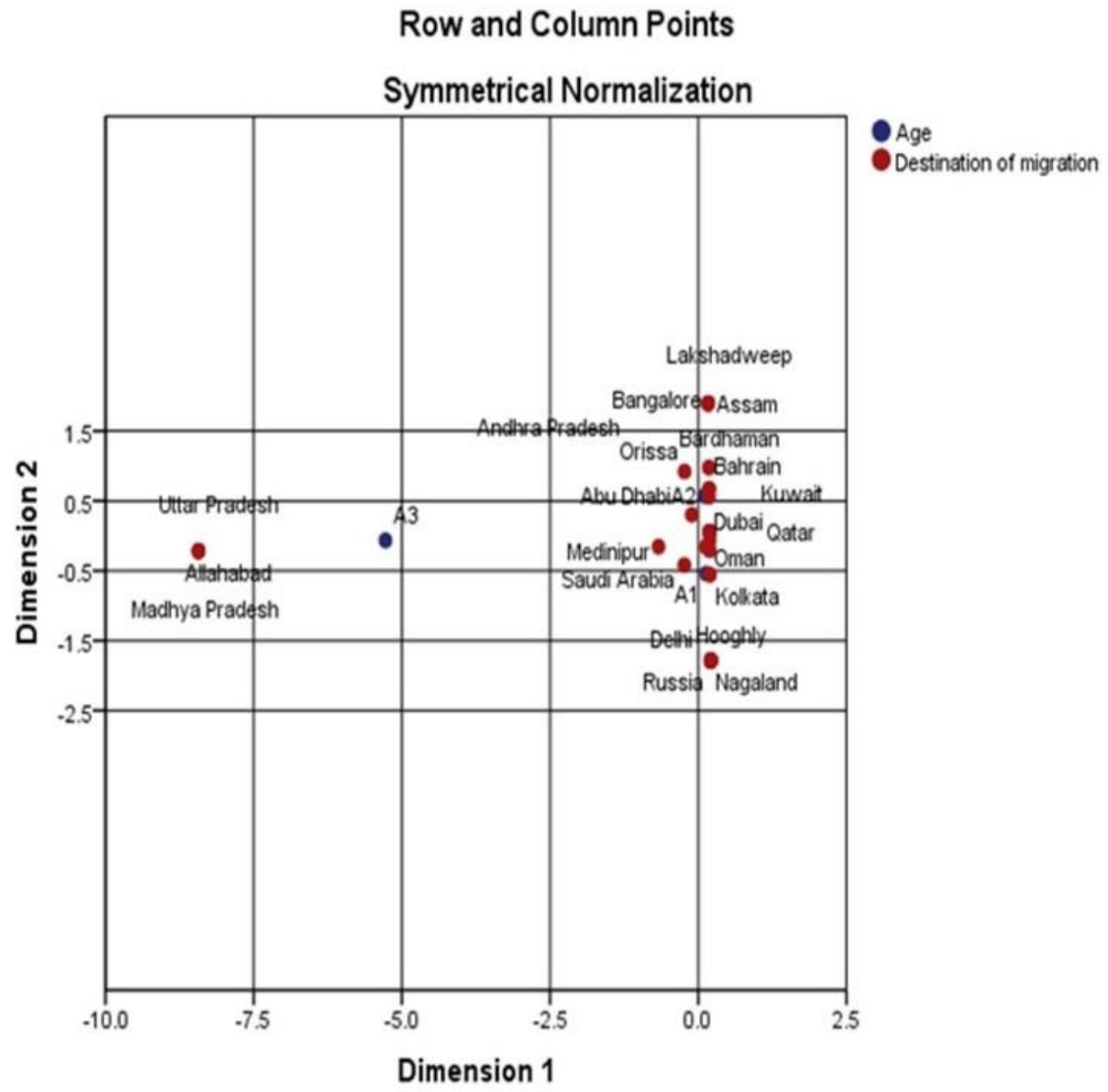

*Note: Age of migrants, Early adulthood $(\mathrm{A} 1)=$ upto 34 years; Midlife $(\mathrm{A} 2)=35$ to 49 years; Mature adulthood $(A 3)=50$ years

Figure 4c: Two Dimensional Correspondence Analysis of Age of Migrant and Destinations of Migration 
Row and Column Points

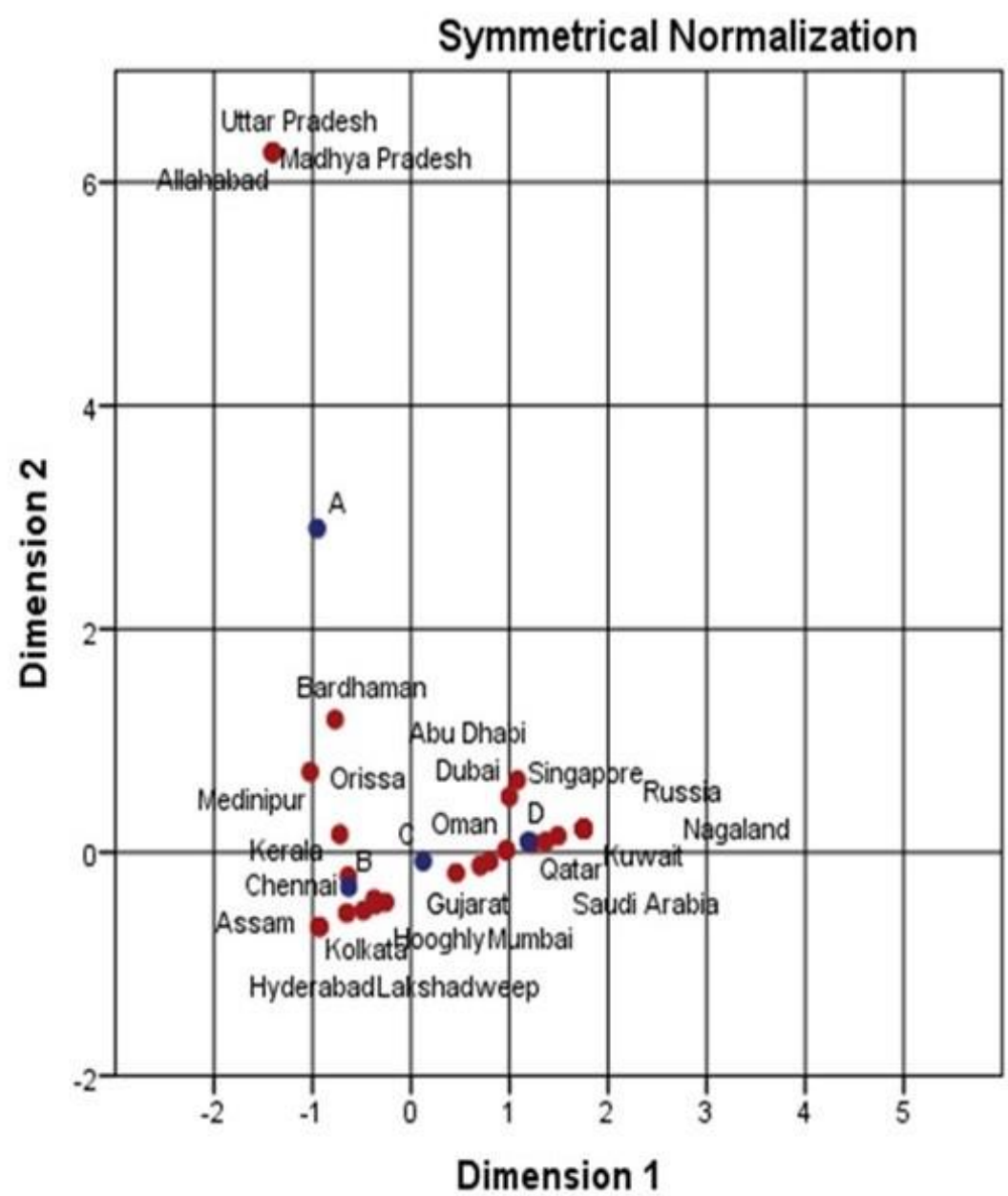

Destination of migration

Remittance

*Note: Remittance (in Rupees, INR), $A=$ up to $28817, B=28818$ to 89167, C=89168 to 149518 and $D=149519$ and above

Figure 4d: Two Dimensional Correspondence Analysis of Remittance and Destination of Migration 


\section{Row and Column Points}

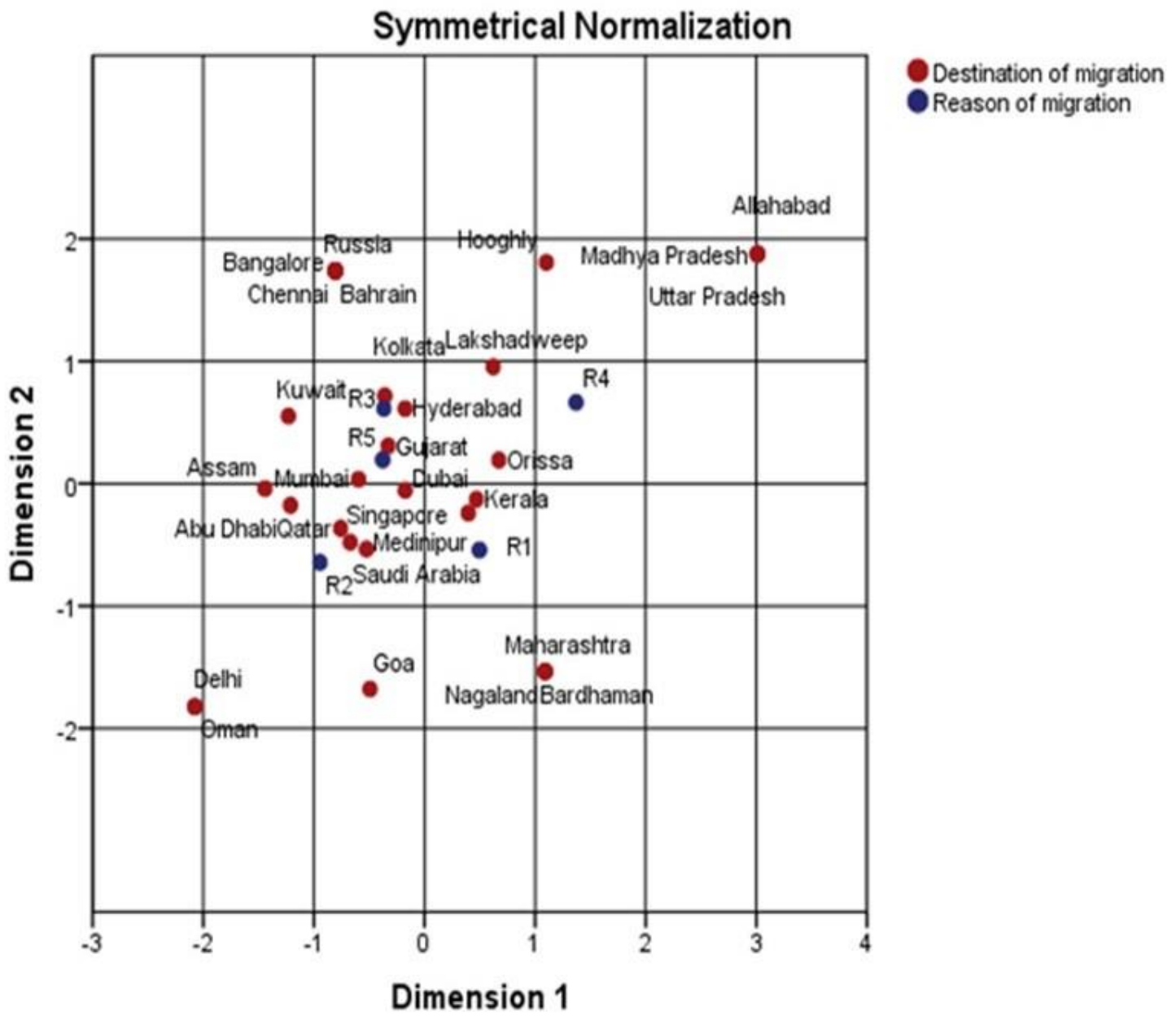

*Note: Reason for migration, $A=$ Household needs, $B=$ Household extra needs or asset creation, $\mathrm{C}=$ Profession, $\mathrm{D}=$ Lump sum money and $\mathrm{E}=$ Others

Figure 4e: Two Dimensional Correspondence Analysis of Reason for Migration and Destination of Migration 
Row and Column Points

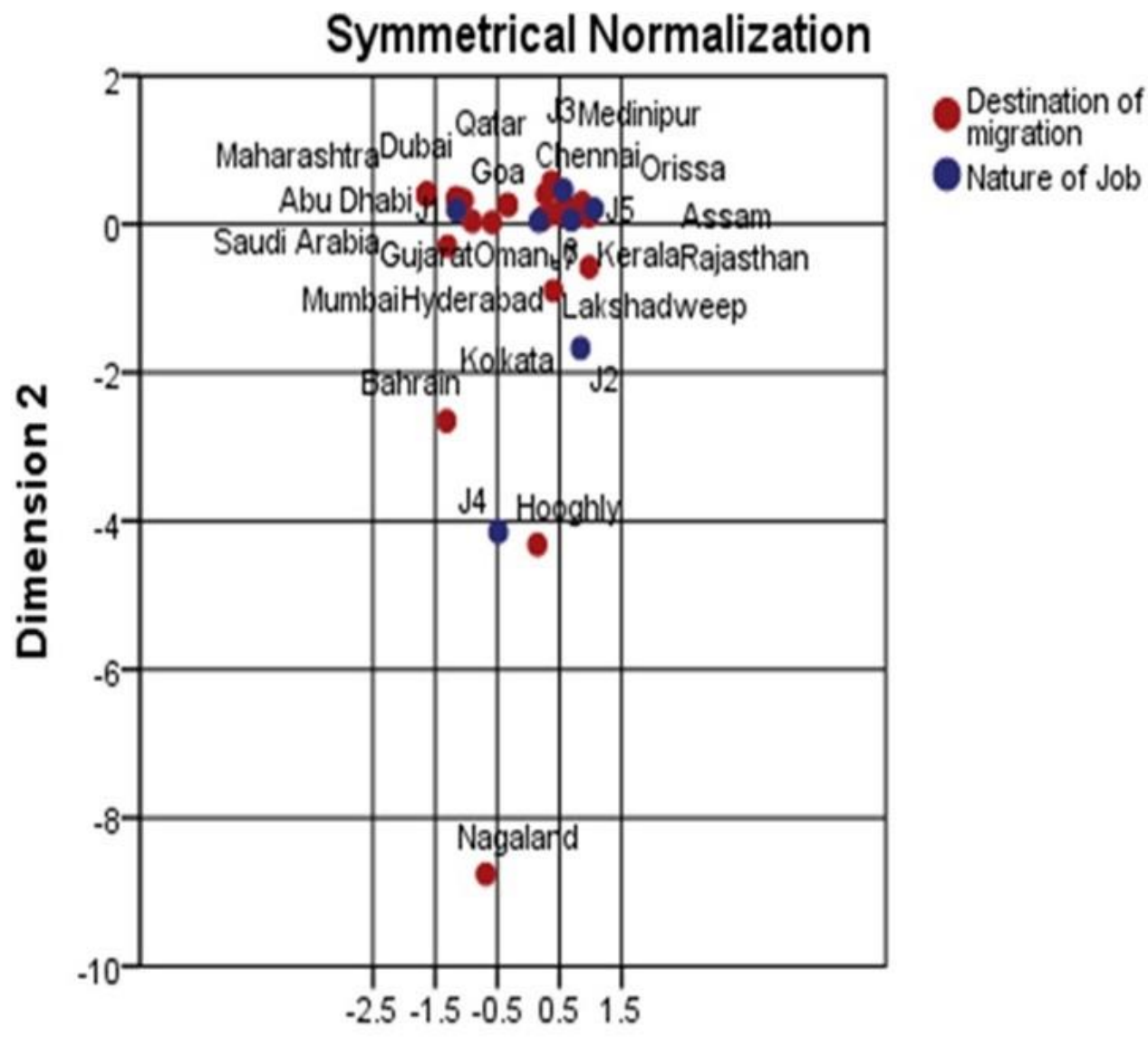

Dimension 1

*Note: Job type, $\mathrm{J} 1=$ Pipe line labour, $\mathrm{J} 2=$ Load and unload, $\mathrm{J} 3=$ Concrete road making labour, $\mathrm{J} 5=$ Helper, $\mathrm{J} 6=$ Trawler driver, $\mathrm{J} 7=$ Construction labour and $\mathrm{J} 8=$ Others

Figure 4f: Two Dimensional Correspondence Analysis of Job Types and Destinations of Migration

\begin{tabular}{|c|c|c|c|c|c|c|c|c|c|c|c|c|}
\hline \multirow[t]{2}{*}{$\begin{array}{c}\text { Destination of } \\
\text { migration }\end{array}$} & \multicolumn{2}{|c|}{$\begin{array}{l}\text { Migration } \\
\text { chronology }\end{array}$} & \multicolumn{2}{|c|}{$\begin{array}{c}\text { Educational } \\
\text { level }\end{array}$} & \multicolumn{2}{|c|}{$\begin{array}{l}\text { Reasons for } \\
\text { migration }\end{array}$} & \multicolumn{2}{|c|}{ Remittance } & \multicolumn{2}{|c|}{ Job types } & \multicolumn{2}{|c|}{ Age } \\
\hline & 1 & 2 & 1 & 2 & 1 & 2 & 1 & 2 & 1 & 2 & 1 & 2 \\
\hline Dubai & -.224 & 1.439 & .122 & -.450 & -.174 & -.056 & .998 & .498 & $\begin{array}{c}- \\
1.017\end{array}$ & .254 & .190 & -.066 \\
\hline Qatar & -1.012 & .217 & $\begin{array}{c}- \\
1.048\end{array}$ & .212 & -.758 & -.366 & 1.365 & .096 & $\begin{array}{c}- \\
1.155\end{array}$ & .296 & .189 & .057 \\
\hline Abu Dhabi & -.514 & 1.445 & .163 & -.359 & -1.212 & -.178 & 1.078 & .647 & 1.155 & .296 & .183 & .559 \\
\hline Saudi Arabia & -.056 & .927 & .188 & -.582 & -.525 & -.535 & .798 & -.081 & $\begin{array}{c}- \\
1.139\end{array}$ & .284 & -.236 & -.417 \\
\hline Oman & -.005 & 1.191 & .258 & $\begin{array}{c}- \\
1.523\end{array}$ & -2.076 & -1.823 & .966 & .019 & .662 & .000 & .189 & .057 \\
\hline Bahrain & -.320 & 1.996 & .147 & $\begin{array}{c}- \\
2.702\end{array}$ & -.807 & 1.739 & 1.228 & .083 & $\begin{array}{c}- \\
1.308\end{array}$ & $\begin{array}{c}- \\
2.619\end{array}$ & .181 & .670 \\
\hline Kuwait & -4.014 & -1.064 & $\begin{array}{c}- \\
2.097\end{array}$ & -.462 & -1.230 & .552 & 1.752 & .210 & $\begin{array}{c}- \\
1.628\end{array}$ & .347 & .181 & .670 \\
\hline Russia & -11.322 & -4.205 & .258 & $\begin{array}{c}- \\
1.523\end{array}$ & -.807 & 1.739 & 1.752 & .210 & $\begin{array}{c}- \\
1.628\end{array}$ & .347 & .212 & $\begin{array}{c}- \\
1.784\end{array}$ \\
\hline Singapore & -.999 & .855 & $\begin{array}{c}- \\
1.353\end{array}$ & -.405 & -.672 & -.479 & 1.490 & .147 & $\begin{array}{c}- \\
1.276\end{array}$ & -.348 & .189 & .057 \\
\hline Kerala & .237 & -.389 & .321 & .429 & .470 & -.127 & -.639 & -.215 & .756 & .060 & .125 & -.158 \\
\hline
\end{tabular}




\begin{tabular}{|c|c|c|c|c|c|c|c|c|c|c|c|c|}
\hline Gujarat & .169 & .062 & -.037 & -.108 & -.328 & .308 & .457 & -.185 & -.623 & .090 & -.112 & .301 \\
\hline Mumbai & .184 & -.073 & -.228 & -.263 & -.597 & .035 & .701 & -.120 & -.928 & .070 & .189 & .057 \\
\hline Hyderabad & .312 & -.442 & -.828 & .526 & -.175 & .612 & -.483 & -.521 & .423 & .068 & .192 & -.206 \\
\hline Orissa & .086 & .316 & -.341 & .117 & .673 & .192 & -.722 & .161 & .596 & .300 & -.232 & .920 \\
\hline Chennai & -.414 & 1.171 & $\begin{array}{c}- \\
1.636\end{array}$ & .477 & -.807 & 1.739 & -.653 & -.543 & .253 & .532 & .189 & .057 \\
\hline Hooghly & .439 & -1.095 & .007 & -.700 & 1.101 & 1.808 & -.375 & -.420 & .151 & $\begin{array}{c}- \\
4.242\end{array}$ & .212 & $\begin{array}{c}- \\
1.784\end{array}$ \\
\hline Bardhaman & .270 & -.443 & .253 & -.334 & 1.090 & -1.535 & -.771 & 1.190 & .200 & 1.101 & .177 & .977 \\
\hline Kolkata & .344 & -.709 & .433 & -.514 & -.359 & .716 & -.367 & -.471 & .425 & -.914 & .196 & -.557 \\
\hline Medinipur & .211 & -.168 & .352 & .055 & .396 & -.240 & $\begin{array}{c}- \\
1.025\end{array}$ & .720 & .855 & .370 & -.671 & -.155 \\
\hline Nagaland & .439 & -1.095 & $\begin{array}{c}- \\
6.806\end{array}$ & 1.661 & 1.090 & -1.535 & 1.752 & .210 & -.669 & 8.550 & .212 & 1.784 \\
\hline Delhi & .439 & -1.095 & -.243 & .123 & -2.076 & -1.823 & 1.752 & .210 & 1.628 & .347 & .212 & $\begin{array}{c}- \\
1.784\end{array}$ \\
\hline Goa & .439 & -1.095 & .251 & .062 & -.493 & -1.679 & 1.752 & .210 & -.328 & .206 & .212 & $\begin{array}{c}- \\
1.784\end{array}$ \\
\hline Bangalore & -1.157 & 2.107 & .245 & 1.647 & -.807 & 1.739 & 1.752 & .210 & 1.628 & .347 & .166 & 1.897 \\
\hline $\begin{array}{l}\text { Andhra } \\
\text { Pradesh }\end{array}$ & .439 & -1.095 & .245 & 1.647 & -.807 & 1.739 & 1.752 & .210 & $\begin{array}{c}- \\
1.628\end{array}$ & .347 & .166 & 1.897 \\
\hline Allahabad & -.469 & 1.836 & .258 & 1.523 & 3.010 & 1.877 & 1.404 & 6.268 & .352 & -.067 & $\begin{array}{c}- \\
8.431\end{array}$ & -.216 \\
\hline $\begin{array}{l}\text { Madhya } \\
\text { Pradesh }\end{array}$ & -.005 & 1.191 & .258 & $\begin{array}{c}- \\
1.523\end{array}$ & 3.010 & 1.877 & $\begin{array}{c}- \\
1.404\end{array}$ & 6.268 & .352 & -.067 & $\begin{array}{c}- \\
8.431\end{array}$ & -.216 \\
\hline Uttar Pradesh & .439 & -1.095 & .258 & 1.523 & 3.010 & 1.877 & 1.404 & 6.268 & .352 & -.067 & $\begin{array}{c}- \\
8.431\end{array}$ & -.216 \\
\hline Maharashtra & .217 & .048 & .007 & -.700 & 1.090 & -1.535 & .966 & .019 & -.328 & .206 & .212 & $\begin{array}{c}- \\
1.784\end{array}$ \\
\hline Lakshadweep & .328 & -.524 & .499 & .837 & .621 & .955 & -.260 & -.448 & .958 & -.364 & .166 & 1.897 \\
\hline Assam & .217 & .048 & .997 & .789 & -1.442 & -.042 & -.930 & -.667 & .972 & .066 & .166 & 1.897 \\
\hline Rajasthan & .439 & -1.095 & .258 & 1.523 & -.807 & 1.739 & -.930 & -.667 & .972 & .066 & .212 & $\begin{array}{c}- \\
1.784\end{array}$ \\
\hline
\end{tabular}

\section{Chronology of Migration}

For the first time (D1), the migrants preferred travelling to Kerala, Hyderabad, Delhi, Nagaland, Goa, and Hooghly (Figure. 4a). Those who pursued a second journey (D2), were more likely to go to Gujarat, Mumbai, and Orissa and then in their third journey (D3) they moved to Chennai, Allahabad, Singapore, and Abu Dhabi. In the fourth (D4) and fifth journey (D5), they preferred moving to Dubai, Bahrain, Saudi Arabia, and Oman.

Overall, we find a gradual shift of destinations from state to national to international locations. This transition is understandable since the first journey was often tentative because the migrants had little experience of the uncertainties associated with migration and preferred to go to places wherefrom they could come back easily. With the increased experience and savings from the first or initial migration/s, the migrants became more confident. They were able to support their transition to international destinations with their saved money. A key informant who acted as a labour agent said:

They first started migrating to Mumbai, Gujarat, and Hyderabad to gather skill, knowledge, and money; then they made their way abroad

\section{Education}

The migrants who had attended college went to Russia, Bahrain, Oman, and Rajasthan, Uttar Pradesh, Madhya Pradesh, and Allahabad. In contrast, less educated people (5 to 8 grade) were more likely to move to Dubai, Abu Dhabi and Saudi Arabia (Figure 4b). Migrants with a little higher education (9-10 grade) travelled to Orissa and Delhi and with a secondary level of education moved to Mumbai and Gujarat. Some of the migrants, who migrated to Kuwait, Singapore, Qatar, Chennai, and Hyderabad, were educated up to the secondary and higher secondary levels (11-12). People with primary education (1-4) went to Goa, Medinipur, and 
Kerala, while the illiterates moved to Assam and Lakshadweep.

Interestingly, a part of the international migrants was either from a lower educational status group or from an educated group, whereas migrants moved to all over India irrespective of their educational status. The demand for semi-skilled labour is high in middle-eastern countries, especially in construction works, and the demand for skilled labours is high in oil industries. However, the observation is not conclusive since the same destinations needed people having different levels of skill. Nevertheless, given the fact that only more skilful people transitioned from national to international destinations, it may be debated that it is the skill (and not necessarily education) that shaped the movement to highly remunerative destinations. Also, the level of education of most of the migrants was so low that skill might not correlate with the level of education. Although Keshri and Bhagat (2013) observed that a person with low educational attainment was likely to be engaged more in temporary, regional migration, we found several exceptions. A key informant, who was a school teacher said:

Whether a person should study or not...he will go abroad for earning money.

\section{Age/Life Cycle}

The early adult migrants ( $A 1$, up to 34 years) went to Delhi, Oman, Goa, and Saudi Arabia and the migrants in their midlife (A2, 35 to 49 years) moved to Singapore, Qatar, Saudi Arabia, and Abu Dhabi (Figure 4c). Migrants of the higher age group ( $A 3,50$ years and above) moved to Allahabad, Madhya Pradesh, and Uttar Pradesh.

The young people, often migrating for the first/second time (since it is unlikely that a person starts migration at an advanced age) moved to places within the state and the country. As told earlier, they then explored the opportunity of moving to an international destination, where their improved skills would fetch them a higher wage. At an advanced age, the physical ability and agility of the migrants perhaps went down and the need to support the family back home diminished. However, Kaestner and Malamud (2014) highlighted that age, along with education and cognitive ability, are contributory factors to one's skill acquisition and performance. At the mid-age, the performance of a person is at its best, which is very demanding in the international labour market.

\section{Remittance}

Those who sent back more than INR 149519 (D) per year to their families were more likely to have worked in Bahrain, Qatar, Singapore, Dubai, and Abu Dhabi (Figure 4d). Remittance in the range of INR 28818 - 89167 (B) was associated with Kerala, Chennai, Hyderabad, Kolkata, Hooghly, Lakshadweep, Assam, and Rajasthan. Those who sent INR 89168 - 149518 (C) in a year tended to go to Gujarat and Mumbai, and those who sent less than INR28817 (A) tended to travel to Allahabad, Madhya Pradesh, and Uttar Pradesh.

Although remittance might presumably be understood as an outcome of choosing a specific destination, a migrant symbolically anticipates the expected remittance even before reaching/deciding upon the destination. In fact, in the modified neoclassical models of migration, destinations are determined by expected rather than actual earning (and remittance) (Krieger \& Maitre, 2006). In that sense, potential remittance acts as a factor that shapes the choice of destination. Families in high need of cash and having higher ambition chose destinations where higher wage rates prevailed (because of payment in foreign currency). However, those who could not bear the expense of transition or did not have access to the support network to facilitate the same chose national destinations such as Gujarat, Mumbai, and others. Migrants with lower skill set moved to the regional or national destinations. The perceived probability of the international migrants failing to build 'new property' is also an important factor (Sunam, 2015) as an unsuccessful drive would be difficult to make up by conventional occupations. Investment in migration is made only when the wage is high and assured. 


\section{Reasons for Migration}

To fulfil the basic household needs (R1), migrants went to Medinipur, Kerala, and Orissa (Figure 4e). Those who wanted to create assets or earn extra income (R2) moved to Abu Dhabi, Qatar, Dubai, Saudi Arabia, and Mumbai. The migrants who treated migration as a profession (R3) were most likely to move to Kolkata, Madhya Pradesh, Uttar Pradesh, Allahabad, and Chennai. The places like Gujarat, Mumbai, and Dubai were chosen for different reasons of migration (R5) like family conflict and/or illness of family members and/or repayment of a large amount of debt or loan taken in a crisis period. It seemed that migrants travelled to Uttar Pradesh, Madhya Pradesh, and Allahabad and sometimes to Lakshadweep and Kolkata to earn a lump sum of money (R4) and not for fulfilling any specific objective.

Urge to earn cash is often linked to the nature of the family's need. For fulfilling the basic family needs of distressed migrants, the male members moved to regional and national destinations on an ad-hoc basis. On the other hand, families in need to create assets mostly went to international destinations, where high wages prevailed. Some other groups in need of money to handle emergencies moved to places with high wage rates and where the transition was relatively smoother. Another group needing a lump sum of money to finance specific family needs such as ceremonies like a wedding moved to national destinations. In summation, migration satisfied family needs that were presumably unattainable through conventional occupations. During an FGD, an international migrant's wife accepted:

It seems that we are leading a better life.

\section{Nature of Job}

Migrants frequently moved to Qatar, Singapore, Oman, Chennai, and Mumbai to work as labours in pipeline work (J1), whereas some moved to Kerala, Dubai, Hyderabad, and Kolkata to work in building construction (J6) (Figure 4f). To work as a helper in construction work (J5), some migrants travelled to Lakshadweep, Goa, Maharashtra, and Rajasthan. Those who migrated to Allahabad, Madhya Pradesh, Uttar Pradesh, Chennai, and Hyderabad were likely to choose diverse kinds of jobs (J7). Those who wanted to work in concrete road making (J3) perhaps went to Medinipur. To work as labour for loading and unloading of goods (J2), villagers moved to Kolkata; few others moved to Kuwait, Bahrain, and Abu Dhabi for working in the service sector (J4) as supervisors.

The nature of the job is often related to the skill set of migrants. As already stated above, skilled labours migrated to the Middle-East countries for pipeline works (Rajan, 2011), and to fulfil the labour demand of oil industries. Another group of skilled labours moved to the construction works in and outside the country. Unskilled labours mostly moved within the state to work under the road contractor or to other national destinations to help the skilled labours.

In summary, transnational migration was not pursued in the first instance of migration and took place in the later rounds of migration. Lesseducated migrants moved to middle-east countries as construction workers while the labours with a little more education moved to Qutar, Hong Kong, Russia, etc. Inland migration was more likely to happen among early adult, and middle-aged persons mostly pursued late adult migrants and transnational migration. The higher expected remittance often needed to build capital at source, led to transnational migrations in areas where oil pipeline works were on offer. On the other hand, internal migration was a response to family crises and needed relatively lesser remittance saved from internal migrations.

Although correspondence analysis engaged the six factors mentioned above as predominant, these might not be enough to comprehend the context of selection of destination. There are some overarching factors like caste, family type, family decision, assets, support networks, and the dynamics of neoliberal development of an economy that shape the role of these six factors. Caste is an ascribed status, which denotes the position of a person in society. People from the upper caste, already occupied higher economic and social positions in society, could afford the 
cost of transnational migration. On the other hand, migrants belonging to underprivileged castes tended to move to regional or national destinations of Central and North India (Keshri \& Bhagat, 2013). Migration to overseas destinations was easier in joint extended families, where other family members would provide security to the spouse, children and parents, which was not possible in nuclear families (Saha, Goswami, \& Paul, 2018). The household members of joint families bore the cost and shared the benefits of migration. Sometimes, the cost of a failed international migration for a nuclear family would worsen the economic condition. International migrants earned more and spent a remarkable amount for upgrading their economic status, especially by the creation of ostensible assets. Also, they would utilise this either in covering the cost of another international trip (to a country with a higher currency rate) or by sending another family member to overseas destinations.

Additionally, a secure and supportive network system, coupled with the ability to cover migration costs, facilitated the transitions of migrants to overseas destinations (Vertovec, 2002). The labour outflow to the fulfilment of massive skilled labour demand of the Middle East, Singapore and Malaysia happens due to the fast growth of oil and other related construction industries there. Based on the success stories of migrants, some of the internal migrants (after developing their specific skills when working as regional labours) and first-time migrants planned to make voyages to the overseas destinations with the help of existing support networks. However, the spread of the migration diaspora was possible due to the expansion of the neoliberal economy in different corners of the globe and thereby opening up the international labour markets to the underdeveloped parts of the world (Munck, Ulrik Schierup, \& Delgado Wise, 2011). Recent research suggests that the shift from internal to international migration may be guided by crossspace consumption that is, the social value of consumption apart from/on top of all the other factors mentioned above (Zhou \& Li, 2016).

\section{Conclusion}

Migration is inevitable in rural India, and it has increasingly been seen as the most common way of generating cash income for rural poor in the context of changing social and demographic dynamics in a liberalised economy. This study examined the diverse destinations, both within and outside the country, of migrants from coastal West Bengal. The research wanted to understand how different factors are associated with the destinations of migration. Like many other developing countries, the selection of destination (of migration) in Sundarbans is regulated by the education and age of migrants, remittance, the reason for migration, nature of the job at destination and chronology of migration.

For many households, internal migration was sufficient to maintain basic household needs and to increase household resilience against emergencies. However, this was not enough to develop physical capital at the origin, and a significant portion of migrants travelled to overseas countries to earn additional cash for earning a better future. Livelihoods of the study region are expected to depend on male outmigration to international and national destinations irrespective of the changes in the agricultural and non-agricultural sectors in the short-run. Higher wage defined by the skill and experience of the labours might result in more significant remittance and formation of more capital back home. This accumulation of cash or capital might further increase the cost bearing ability of households to support future migration.

It is anticipated that this comprehensive discussion will inform the policymakers about the dynamics of labour mobility in rural Bengal and put better migration management in place through appropriate policies in a structural setting at the destinations and origin, where it would be applicable (Kelegama, 2011). Academia and policy might develop computational models based on our studied factors for rural India. This argument bear resonance to the arguments as put forwarded by 
Hoda Rahmati and Tularam (2017), and Batista and McKenzie ( 2018).

Since low-skilled labours are more exposed to wage exploitation and improper living and working conditions, the government's skill development programme may focus on the promotion of migration of skilled workers. Slow growth in employment and the enlarged interest in the migration of skilled workers are likely to push the escalation of migration from rural areas. As suggested by ILO (2016), a revision in the migration policy framework could be introduced that maintains a balance between inspiring migration and providing protection to migrant workers at destinations.

Since there is inherent diversity in the rural livelihoods and their trajectories in the coastal saline zone of West Bengal, the small number of study locations and limited sample size may not accurately represent the population of Sundarbans. Moreover, the representation of multiple correspondence analysis on a twodimensional space may allow for minor misinterpretations.

\section{References}

Ali, S. (2007). 'Go west young man': The culture of migration among Muslims in Hyderabad, India. Journal of Ethnic and Migration Studies, 33(1), 37-58. doi:10.1080/13691830601043489

Balica, E., \& Marinescu, V. (Eds.) (2018). Migration and Crime: Realities and Media Representations. Cham, Switzerland: Springer Nature Switzerland AG.

Barrientos, S. W. (2013). 'Labour chains': analysing the role of labour contractors in global production networks. The Journal of Development Studies, 49(8), 1058-1071. doi:10.2139/ssrn.1895292

Batista, C., \& McKenzie, D. (2018). Testing Classic Theories of Migration in the Lab. Mimeo, Universidade Nova de Lisboa and World Bank. Retrieved on 12 December 2019 from http://conference.iza.org/conference_files/AM M_2019/batista_c2249.pdf

Bauer, T., \& Zimmermann, K. F. (1999). Assessment of possible migration pressure and its labour market impact following EU enlargement to Central and Eastern Europe (IZA Research Report No. 3). Retrieved on 14 March 2019 from

http://legacy.iza.org/en/webcontent/publicatio ns/reports/report_pdfs/report_pdfs/iza_report _03.pdf

Berger, M. C., \& Blomquist, G. C. (1992).

Mobility and destination in migration decisions:

The roles of earnings, quality of life, and

housing prices. Journal of Housing

Economics, 2(1), 37-59. doi:10.1016/1051-

1377(92)90018-I

Brettell, C. B., \& Hollifield, J. F. (Eds.). (2014). Migration theory: Talking across disciplines. New York, NY: Routledge.

Brown, W. (2006). American nightmare: Neoliberalism, neoconservatism, and dedemocratization. Political Theory, 34(6), 690714. doi:10.1177/0090591706293016

Brown, T., Scrase, T. J., \& Ganguly-Scrase, R. (2017). Globalised dreams, local constraints: migration and youth aspirations in an Indian regional town. Children's Geographies, 15(5), 531-544. doi:10.1080/14733285.2016.1274948

Crawley, H., Duvell, F., Jones, K., McMahon, S., \& Sigona, N. (2016). Destination Europe? Understanding the dynamics and drivers of Mediterranean migration in 2015. MEDMIG Final Report. Retrieved on 17 September 2019 from http://www.medmig.info/research-briefdestination-europe/

Creswell, J.W. (2012). Educational Research:

Planning, Conducting, and Evaluating

Quantitative and Qualitative Research ( $4^{\text {th }}$ ed.). New Jersey: Pearson Education Inc.

Czaika, M. (2012). Internal versus international migration and the role of multiple deprivation: Some evidence from India. Asian Population

Studies, 8(2), 125-149. doi:10.1080/17441730.2012.675678

Deshingkar, P. (2004). Understanding the implications of migration for pro-poor agricultural growth. Paper prepared for the DAC POVNET Agriculture Task Group Meeting, Helsinki. Retrieved on 2 March 2018 from 
http://www.oecd.org/dac/povertyreduction /36562999.pdf

Deshingkar, P. (2008). Circular internal migration and development in India. In J. de Wind, \& J. Holdaway (eds.), Migration and development within and across broader: Research and policy perspectives on internal and international migration (pp. 161-188). Geneva and New York: International Organization of Migration; Social Science Research Council.

District Human Development Report: South 24 Parganas. (2009). Development and Planning Department Government of West Bengal. Retrieved on 24 September 2015 from http://www.undp.org/content/dam/india/docs /hdr_south24_parganas_2009_full_report.pdf

Fafchamps, M., \& Shilpi, F. (2008).

Determinants of choice of migration destination, World Bank Policy Research (CSAE WPS/2009-09). Retrieved on 22 December 2018 from

https://www.csae.ox.ac.uk/materials/papers/2 009-09text.pdf

Fawcett, J. T. (1989). Networks, linkages, and migration systems. International Migration Review, 23(3), 671-680. Doi :10.2307/2546434

Fernando, M., \& Giordano, C. (2016). Introduction: Refugees and the crisis of Europe. Cultural Anthropology, 28. Retrieved on 27 November 2019 from https://culanth.org/fieldsights/introductionrefugees-and-the-crisis-of-europe

Ganguly-Scrase, R. (2003). Paradoxes of globalization, liberalization, and gender equality: The worldviews of the lower middle class in West Bengal, India. Gender \& Society, 17(4), 544-566.

doi:10.1177/0891243203254077

Gimpel, J. G. (1999). Separate destinations: Migration, immigration, and the politics of places. United Sates: University of Michigan Press.

Greenwood, M. J. (1985). Human migration: Theory, models, and empirical studies. Journal of Regional Science, 25(4), 521-544. doi:10.1111/j.1467-9787.1985.tb00321.x

Greenwood, M. J. (1997). Internal migration in developed countries. Handbook of Population and Family Economics, 1, 647-720. doi.org/10.1016/S1574-003X(97)80004-9

de Haan, A. (1999). Livelihoods and poverty: The role of migration-a critical review of the migration literature. The Journal of Development Studies, 36(2), 1-47. doi:10.1080/00220389908422619

de Haan, A. (2002). Migration and livelihoods in historical perspective: A case study of Bihar, India. Journal of Development Studies, 38(5), 115-142. doi:10.1080/00220380412331322531

de Haan, A., \& Rogaly, B. (2002). Introduction: Migrant workers and their role in rural change. Journal of Development Studies, 38(5), 1-14. doi:10.1080/00220380412331322481

de Haas, H. (2010). Migration and development: a theoretical perspective. International

Migration Review, 44(1), 227- 264. doi:10.1111/j.1747-7379.2009.00804.x

de Jong, G. F., \& Fawcett, J. T. (1981).

Motivations for migration: an assessment and a value-expectancy research model. In G.F. De Jong, \& R.W. Gardner (Eds.), Migration decision making: multidisciplinary approaches to micro level studies in developed and developing countries (pp.13-58). New York: Pergamon.

Harris, J. R., \& Todaro, M. P. (1970). Migration, unemployment and development: a two sector analysis. The American Economic Review, 60(1), 126-142.

Hoda Rahmati, S., \& Tularam, G. A. (2017). A critical review of human migration models. Climate Change, 3(12), 924-952.

Hoffman, D. L., \& Franke, G. R. (1986). Correspondence analysis: graphical representation of categorical data in marketing research. Journal of Marketing Research, 23(3), 213-227. doi:10.2307/3151480

Hyll, W., \& Schneider, L. (2014). Relative deprivation and migration 
preferences. Economics Letters, 122(2), 334337. doi:10.1016/j.econlet.2013.12.023

ILO. (2016). India International Labour Migration Update. New Delhi: International Labour Organization.

Islam, N. (1996). Dhaka: from city to megacity: perspectives on people, places, planning, and development issues (No. 1). Dhaka: University of Dhaka.

Kaestner, R., \& Malamud, O. (2014). Selfselection and international migration: New evidence from Mexico. Review of Economics and Statistics, 96(1), 78-91.

doi:10.3386/w15765

Kelegama, S. (Ed.). (2011). Migration, remittances and development in South Asia. New Delhi: Sage Pub.

Keshri, K., \& Bhagat, R. B. (2013).

Socioeconomic determinants of temporary labour migration in India: A regional analysis. Asian Population Studies, 9(2), 175195. doi:10.1080/17441730.2013.797294

Knight, J., Thompson, A., \& Lever, J. (2017). Social network evolution during long-term migration: a comparison of three case studies in the South Wales region. Social Identities, 23(1), 56-70. doi:10.1080/13504630.2016.1207511

Krieger, H., \& Maitre, B. (2006). Migration Trends in an Enlarging European Union. Turkish Studies, 7(1), 45-66. doi:10.1080/14683840500520584

Lindquist, J., Xiang, B., \& Yeoh, B. S. (2012). Opening the black box of migration: Brokers, the organization of transnational mobility and the changing political economy in Asia. Pacific Affairs, 85(1), 7-19. doi:10.5509/20128517

Massey, D. S., Arango, J., Hugo, G., Kouaouci, A., Pellegrino, A., \& Taylor, J. E. (1993). Theories of international migration: A review and appraisal. Population and Development Review, 19(3), 431-466. doi:10.2307/2938462

Mistri, A. (2013). Migration and sustainable livelihoods: a study from Sundarban biosphere reserve. Asia- Pacific Journal of Social Science, 5(2), 76-102.
Mosse, D., Gupta, S., Mehta, M., Shah, V., Rees, J. F., \& Team, K. P. (2002). Brokered livelihoods: Debt, labour migration and development in tribal western India. Journal of Development Studies, 38(5), 59-88. doi:10.1080/00220380412331322511

Munck, R., Ulrik Schierup, C., \& Delgado Wise, R. (2011). Migration, work, and citizenship in the new world order. Globalizations, 8(3), 249260. doi:10.1080/14747731.2011.576553

Ozden, S., \& Mendes, M. (2005). The usage of multiple correspondence analysis in rural migration analysis. New Medit, 4(4), 36-41.

Pallister-Wilkins, P. (2016). Interrogating the Mediterranean 'migration crisis'. Mediterranean Politics, 21(2), 311-315. doi:10.1080/13629395.2016.1145826

Phillips, N. (2011). Informality, global production networks and the dynamics of 'adverse incorporation'. Global Networks, 11(3), 380-397. doi:10.1111/j.1471-

0374.2011.00331.x

Pieke, F. N., \& Biao, X. (2009). Legality and labour: Chinese migration, neoliberalism and the state in the UK and China. Geopolitics, History and International Relations, 1(1), 11-45.

Portes, A. (1997). Immigration theory for a new century: Some problems and opportunities. International Migration Review, 31(4), 799-825. doi:10.2307/2547415

Rajan, S. I. (Ed.). (2011). Migration, identity and conflict: India migration report 2011. New Delhi: Routledge.

Ravenstein, E.G. (1885). The Laws of Migration. Journal of the Statistical Society of London, 48(2), 167-235.

Rose, D. (2001). Revisiting feminist research methodologies: A working paper. Status of Women Canada, Research Division. Retrieved on 22 February 2018 from http://citeseerx.ist.psu.edu/viewdoc/download ?doi=10.1.1.462.4638\&rep=rep1\&type=pdf

Roy, A. K., Singh, P., \& Roy, U. N. (2015). Impact of Rural-urban Labour Migration on Education of Children: A Case Study of Left behind and 
Accompanied Migrant Children in India. Space and Culture, India, 2(4), 17-34.

doi:10.20896/saci.v2i4.74

Saha, S., Goswami, R., \& Paul, S. K. (2018).

Recursive Male Out-migration and the Consequences at Source: A Systematic Review with Special Reference to the Left-behind Women. Space and Culture, India, 5(3), 30-53. doi:10.20896/saci.v5i3.289

Stark, O., 1991. The Migration of Labour. Cambridge \& Oxford: Blackwell

Sunam, R. (2015). In search of pathways out of poverty: mapping the role of international labour migration, agriculture and rural labour. Journal of Agrarian Change, 17(1), 6780. doi:10.1111/joac.12136

Tashakkori, A., \& Teddlie, C. (Eds.). (2010). Sage handbook of mixed methods in social \& behavioral research. Thousand Oaks, CA: Sage.

Thompson, P. A. (1995). Correspondence analysis in statistical package programs. The American Statistician, 49(3), 310-316. doi:10.2307/2684206

Tobler, W. (1995). Migration: Ravenstein, Thornthwaite and Beyond. Urban Geography, 16(4), 327-343. doi:10.2747/0272-

3638.16.4.327

United Nations Conference on Trade and Development. (2011). Impact of Remittances on Poverty in Developing Countries. New York and Geneva: United Nations.

Vertovec, S. (2002). Transnational Networks and Skilled Labour Migration. ESRC Transnational Communities Programme (Working paper WPTC-02- 02). Oxford, England: University of Oxford.

Wahba, J. (2014). Return migration and economic development. In R.E. Lucas (Eds), International handbook on migration and economic development (pp. 327-349). UK: Edward Elgar Publishing Ltd.

Warner, K., Hamza, M., Oliver-Smith, A., Renaud, F., \& Julca, A. (2010). Climate change, environmental degradation and migration. Natural Hazards, 55(3), 689-715. doi: 10.1007/s11069-009-9419-7

World Bank. (2018). Migration and Remittances: Recent Developments and Outlook. Washington DC: World Bank Group.

Yin, R. K. (2006). Mixed methods research: Are the methods genuinely integrated or merely parallel? Research in the Schools, 13(1), 41-4

Zachariah, K.C., \& Rajan, S.I. (2007). Economic and social dynamics of migration in Kerala, 1999-2004: Analysis of panel data (Working papers, no.384). Trivandrum: Centre for Development Studies.

Zhou, M., \& Li, X. (2016). Cross-space Consumption among Undocumented Chinese Immigrants in the United States. Sociology of Development, 2(2), 158-182.

doi:10.1525/sod.2016.2.2.158

Zuniga, V., \& Hernandez-Leon, R. (Eds.). (2005). New destinations: Mexican immigration in the United States. New York, NY: Russell Sage Foundation.

\section{About the Authors}

Shatabdi Saha is a doctoral student at the Integrated Rural Development and Management Faculty Centre of Ramakrishna Mission Vivekananda Educational and Research Institute (RKMVERI). She is working with Rupak Goswami on migration left-behind nexus in the Indian Sundarbans. Ms Saha has academic training in both Rural Development and Social Work and has also worked on the broader issues of women and child health in the voluntary sector. At present, she is working as a Project Scientist (Scientist - C) of Social Science at the National Institute of Cholera and Enteric Diseases of Indian Council of Medical Research.

Rupak Goswami is an Assistant Professor at RKMVERI and a visiting scholar at the University of California, Davis. He is trained in Agricultural Extension and works on diverse issues related to the socio-economics of agriculture. 